\title{
Engineering-Scale In Situ
}

Vitrification of Simulated

Oak Ridge National Laboratory

Liquid Waste Seepage Trenches

\author{
M. E. Peterson \\ T. D. Powell \\ C. L. Tirmmerman
}

March 1992

Prepared for the

Oak Ridge National Laboratory

under a Related Services Agreement

with the U.S. Department of Energy

Contract DE-AC06-76RLO 1830

Pacific Northwest Laboratory

Operated for the U.S. Department of Energy

by Battelle Memorial Institute

\section{Baftelle}




\title{
DISCLAIMER
}

This repont was, prepared as an account of wonk spomsoned by am agency' of the United!States: (Uovenmment. Neithen the Unired Sticies, Covenment mor any agency thereoti, mon Battelle Mermoniall Institute, mor any of their emplioyees, makes any' warranty, expressed or implied, or assumes any/legal liability or responsibility lor the accunacy, completeness, or usefulness of any information, apparatus, product, or process disclosed, or nepresents, that its use would not infringe privately' owned rights. Refenence hereintoany specific commenciall product, process, on service by inade mame, tradtemank, mamufiacturen, on othenwise does mot necessanily comstitute. on imply: its: endorsement, necommendation; on favonings, by the United States Government on any' agency thenerfi, on Battelles Memoniall instifute. The views, and opimions of authons expressed thetein do mol necessarily state on reillect those of the United States Govennment on any agency theneol.

\author{
PACIFIC NORTHHWWESTLABORATORYY \\ operated by \\ BATTELLE MEMORIALL INSTITUTEE \\ for the \\ UNNITED STATES DEPAARTMENT: OF ENERCY \\ under Contract DE.ACOG.76RLO' 18:30:
}

Printed in the United States of America

Available to DOE and DOE contractors from the

Office of Scientific and Technical! Infonmation, P.O. Box 62, Oak Ridige, TIN 371337; prices available from (615): 576-84011. FTS 6.26-81407.

Available to the public from the National Technical Infonmation Service,

U.S. Depiartment of Commerce, 5285 Pont Royal Rd, Springfield, VA 2276.1. 


\section{E. Peterson \\ T. D. Powel1 \\ C. L. Tinmerman}

March 1992

Prepared for the

Oak Ridge National Laboratory under a Related Services Agreement with the U.S. Department of Energy

Contract DE-ACO6-76RLO 1830.

Pacific Northwest Laboratory

Richliand, Washington 99352

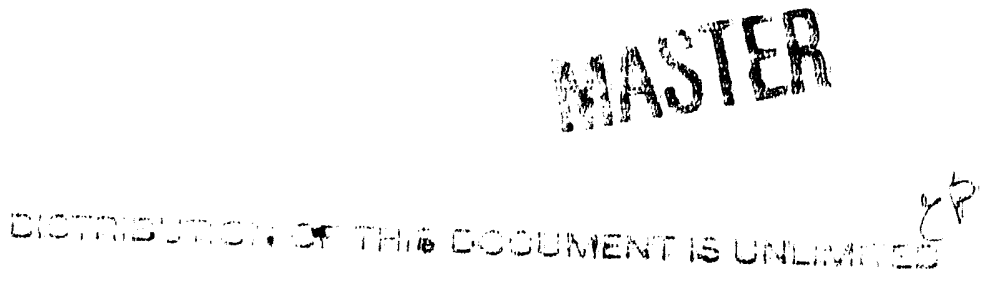




\section{SUMMARYY}

An englineering-scalle test of in sittu vitriffication (ISV) was successfulliy compileted in January 1990 using: Oak Ridge Nationall Laboratory (ORNL) nonradioactive cesium (Cs)-spiiked soijls. The objectives of this engineering-scalle ISV test were to: 1) assess the applitication of ellectrode feedling to ORNL soills; 2) evailuate severall reali-time temperature monitoring methods: for the melit; 3) evaliuate $C s$ retention in the glass; and 4) determine the effectiveness of a pretreatment fillter for removal of cs from the off-gas stream. The test was part of a larger program to determine the applicability. of the ISV process as a remedliall action techinique for the treatment of ORNL litiquid waste seepage trenches.

The test produced a $511 \mathrm{~cm}(20 \mathrm{in.}) \times 511 \mathrm{~cm}(20 \mathrm{im}.) \times 56 \mathrm{~cm}(22 \mathrm{in.})$ deep gllass bilock that werighed $23.5 \mathrm{~kg}:(5118 \mathrm{lib})$. The subsidence was $28 \mathrm{~cm}$ (11 in.) from the original surface grade, which is typical of $15 V$ melts and resulits from the densification of the soili and decomposition of the 1 imestome in the trench. The electrode fieeding system operated with no problems during the test indicating the feasibilitity of using this system with ORNL soilis. The ellectrode feeding system eliminated the need for prepilacement of the electrodes in contaminated solils before initiating ISV operations. The thermal monitioring data showed that the melt operating temperature $\left(1300^{\circ}\right.$ to $\left.1475^{\circ} \mathrm{C}\right)$ corresponded with the laboratory-measured temperature at a viscosity of 100 poise, whitich is typical of most ISV operations.

Cesium retention within the me1t was measured at 99.63 wt\%, which was less than the results $(99.99 \%$ and $99.90 \%)$ from previous tests operated under similiar condittions. (Carter, Bates, and Maupin 1987; Carter, Koegler, and Bates, 1988). When the ISV process is changed from engineering to fult scale, this 0.37 wt\% loss to the off gas would create a radiation dose to the operating personnel during ISV remediation of the waste trench. Therefore, a prefilitering method was tested to remove the Cs from the off gas prior to the gases reaching the off-gas treatment system and the operators. By using an in-Tine high-efficiency particulate air (HEPA) fillter prior to the off-gas treatment system, all of the Cs was removed without rapid loading of the 
fillter, which imdlicated the vilability of this method for removing $C$ s during: processing of the Cs-contaminated portion of the waste trench. In addition to this prefilttering technique, thermal monitoring data indicated that reductions in power reduced the melt operating temperature and correspondingly increased melt viscosity. This method could be used to potentially enhance the Cs retemition within the melt by reducing its vapor pressure and its mechanisms of release, such as convective transport within the melt and enhancement of a more impenetrabile colld cap to minimize diffusion and increase entrainment at the melit surface. 


\section{ACKNOWLEDGMENTS}

Pacific Northwest Laboratory gratefully acknowledges Dak Ridge National Laboratory (ORNL) for providing the opportunity to perform this engineering-scalle test. We especially appreciate the support of Gary Jacobs the ORNL scientist responsible for the test, and Mike Naney, the ORNL scientist responsible for the optical thermometry and Type $C$ thermocouples.

Pacific Northwest Laboratory is operated by Battelle Memorial Imstitute for the U.S. Department of Energy under Contract DE-ACO6-76RLO 1830. 


\section{CONTENTS}

SUMMARY ............................................

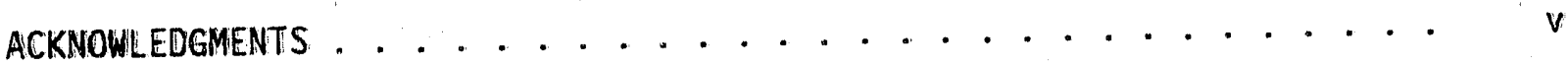

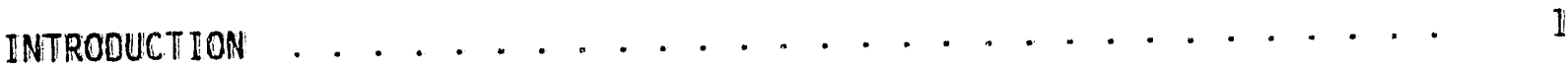

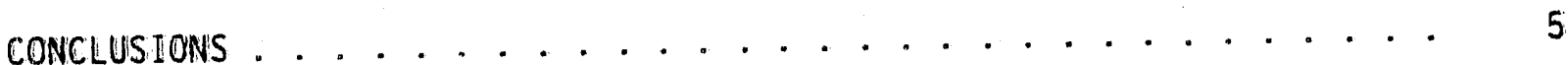

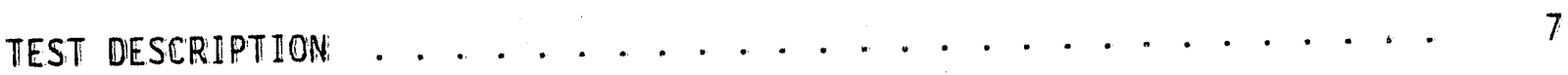

ISV TEST EQUIPMENT ................................ 7

TRENCH CONFIGURATION ............................... 14

THERMAL MONITORING AND PRESSURE INSTRUMENTATION ......... 17

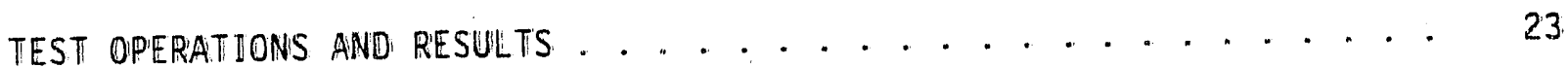

MELT DEPTH VERSUS TIME ........................... 24

Melt Processing Temperature . . . . . . . . . . . 26

Electrical Power ................. . . . 27

Melt Cooldown Temperature ............... 31

Off-Gas System ....................... 32

Glass Samples ......................... 34

Pressure Measurements . . . . . . . . . . . . . 35

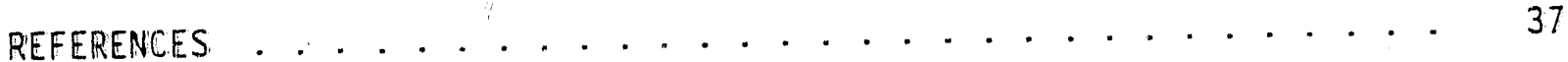

APPENDIX - LABORATORY ANALYTICAL PROCEDURES . . . . . . . . . . A.I 


\section{FIGURES}

1 ISV Process . . . . . . . . . . . . . . . . . . 2

2 Engineering-Scale ISV Equipment.............. 8

3 ISV Engineering-Scale Electrode Feed System . . . . . . . . . 9

4 ISV Engineering-Scale Motor Control Valves for Electrode

Feed System .................... . . 10

5. Engineering-Scale ISV Off-Gas Treatment System . . . . . . 12

6. MM5 Sampling System ................... . 13

7 ORNL Engineering-Scale Trench Configuration . . . . . . . . 16

8 ORNL Engineering-Scale Limestone Trench Before Vitrification . . . 17

9 Blackbody Well/Protection Tube for Accufiber Pyrometer . . . . . 19

10 Blackbody Well/Protection Tube for Accufiber Light Pipe . . . . . . 20

11 Placement of Therrmocouples . . . . . . . . . . . . 21

12 Placement of Blackbody Optical Devices . . . . . . . . . . . 22

13 ISV Bilock Produced During Engineering-Scale Test . . . . . . . . 23

14 Glass Block After Walls Were Removed . . . . . . . . . . 24

I5. Melt Depth vs. Time as Determined by Type $K$ Thermocouples . . . . 25

16. Type C Thermocouple Data . . . . . . . . . . . . . . 26

17 Engineering-Scale Power Data . . . . . . . . . . 27

18 Voltage and Amperage Data for Engineering-Scake Test . . . . . 28

19. Calculated Electrical Resistance During the Engineering-Scale Test ............... . . 29

20. Effects of Power Fluctuation on Melt Temperature ......... 30

21 Me7t Cooldown Temperature................. 31 


\section{TABLES}

1 Composition of ORNL Soil and Limestone . . . . . . . . . . . 14

2 ORNL Type C Thermocouple Protection . . . . . . . . . . . . . 21

3 Cs Release to the Off-Gas System During the Test ........ 33

4 Analysis of Glass Samples . . . . . . . . . . . . . . 34 


\section{INTRODUCTION}

The Pacific Northwest Laboratory (PNL) is developing a remedial action process for contaminated soils that is significant in its application to immobilize or destroy contaminated materials. The process, in situ vitrification (ISV); was developed for the U.S. Department of Energy (DOE) to demonstrate a potential technology for disposal of soil contaminated with transuranic waste at the Hanford Site in southeastern Washington. Tests have demonstrated that hazardous chemical wastes are also destroyed or imnobilized as a result of the process. This report presents continuing efforts and further evidence of the applicability of ISV to Oak Ridge National Laboratory (ORNL) liquid waste seepage trenches.

In situ vitrification is a thermal treatment process that melts contaminated soils to form a glass and crystalline substance. Figure 1 illustrates the ISV process. Four graphite electrodes are inserted a few inches into the ground in a square array. Because soit is not electrically conductive, a mixture of flaked graphite and glass frit is placed among the electrodes to serve as a starter path. Once an electrical potential is applied to the electrodes, an electrical current is initiated in the starter path to begin the melt. The graphite starter path is eventually consumed by oxidation, and the current is transferred to the molten soil, which is processed at temperatures between $1200^{\circ}$ and $2000^{\circ} \mathrm{C}$. As the molten or vitrified zore grows, it incorporates or encapsulates any radionuclides and nonvolatile hazardous elements into the glass structure. The high temperature of the process destroys organic components by pyrolysis. The pyrolyzed by-products migrate to the surface of the vitrified zone and combust in the presence of air. A hood placed over the area being vitrified directs the gaseous effluent to an off-gas treatment system. The molten material, which is trapped in the glass and crystalline product, is then allowed to cool. 


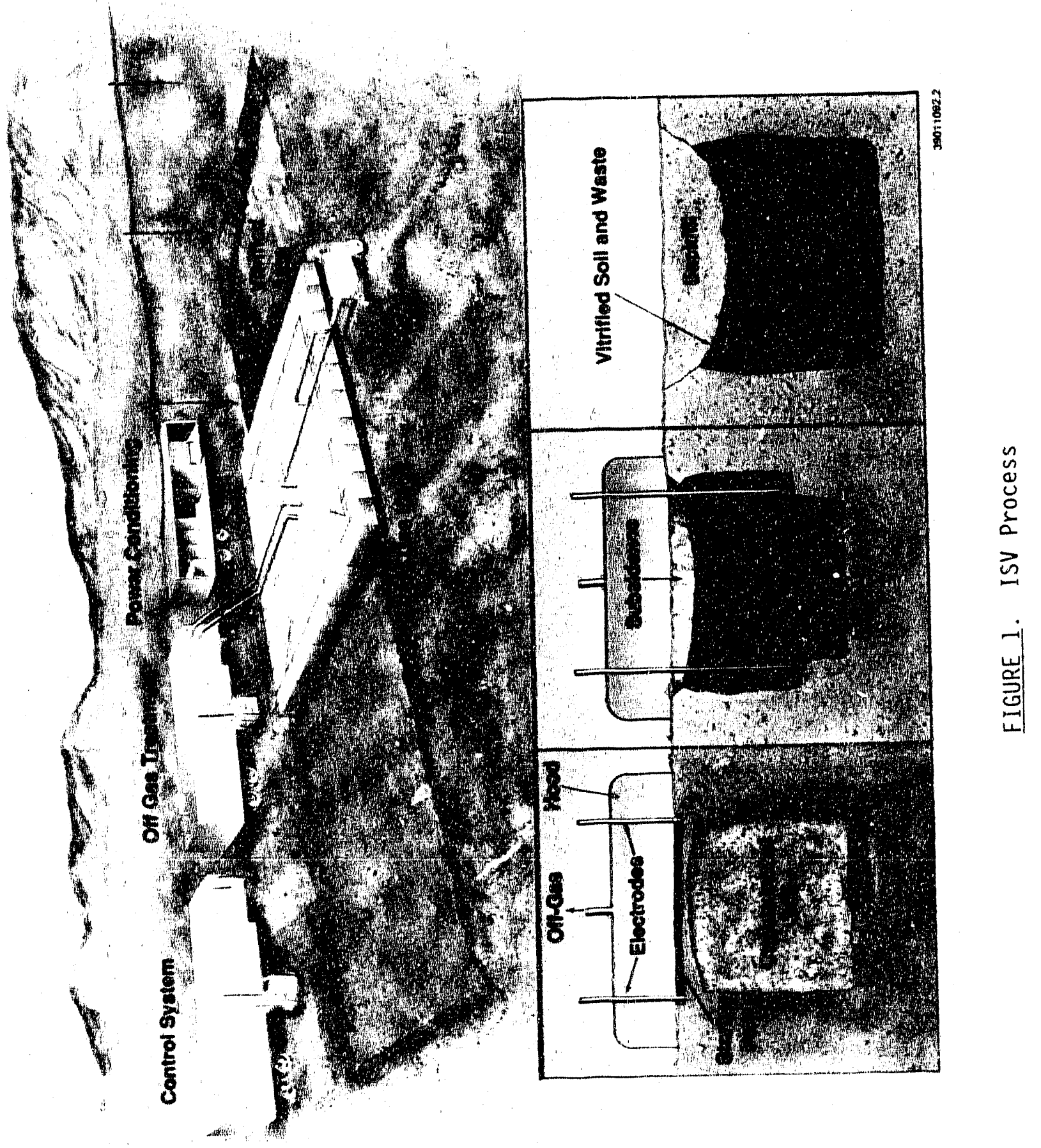


This report presents the results of an engineering-scale ISV test conducted for ORNL. The objectives of this engineering-scale ISV test were to: 1) assess the application of electrode feeding to ORNL soils, 2) evaluate several real-time temperature monitoring methods for the melt, 3 ) evaluate $C s$ retention in the glass, and 4) determine the effectiveness of a pretreatment filter for removal of CS from the off-gas stream. This test is part of a larger program to determine the applicability of the ISV process as a remedial action technique for the treatment of ORNL liquid waste seepage trenches. 
Am englineering-scalle ISV process verifification test was successfuillyy:

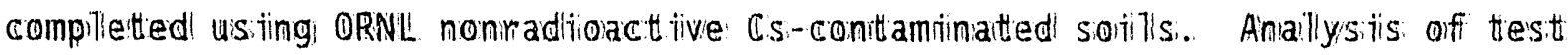
datta provitided the: fiollitiowing concliusions:

- The ellectrode fieeding systtem operatied writhout probillem in the englineeringl-scalle: test, therefore, the appilication of thivis system to ORNL sovills: iis fieasibille.

- The instrumentation: (billackbody opittical devices, and Type c thermocoupiles writh variours coatings and sheathis.) uised to monition me lt temperatures performed well1. Datta from this portion oif the test writili provisde the bas is for a decistion on! which instrumentiation tio use in the pritiot-scaile test.

- Cesium retention within the melt was measured at 99.63 wti, which jis less than measurementts taken from previous tiests. The rellease of 0.37 wto Cs to the off gas willt create a radiiation dose to operating personnel; therefore, the off gas wilit requirre prefititering.

- A high-efficiency particullate air (HEPA) fillter was tested with the standard ISV quenching, scrubbing, and filtering offi-gas treatment systiem to evalluate its effectiveness for Cs removal before Cs reached the offi-gas treatment system $(0.377$ wt\% Cs was relleased to the off gas). The HEPA fillter proved effective; after filtering, no: is was detected downstream.

- In addition to thits prefititering technique, which removes Cs from the off gas, thermal monitoring data indicated that reductions in power reduced the melit operating temperature and therefore, increased melt viscosity. This method could poitentilally enhance is retention within the melt by reducing: vapor pressure and mechantsms of rellease, such as convective transport withitin tive melt and enhancement of a more impenetrabile colld cap to minimize diffiusion and entrainment at the melt surface. This method wit7 be further evaluatted in the piliot-scalle test. 


\section{TESTI DESCRRIPTIION}

Thitis secttion describes the engrimeering-scalle ISV test equilipment, the trench conffiguration, and thermall and pressure moniitoring instirumentattion.

\section{ISVI TESTT EQUIRPMENTI}

The englineeringl-scalle ISV umitt used for thitis test tis shown in figure 2 .

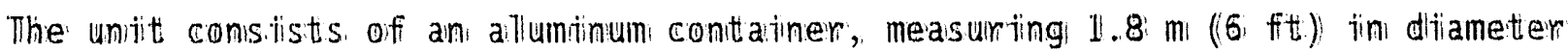
by $2.4 \mathrm{~m}$ ( $(8 \mathrm{ft})$ in height, with an ellectrode fieed system mounted on the cover: of the conttaitiner. The container is sealed alllowing the offi-gas system to remove any gases or particullatte generatted during: the viturification process.

The four electrodes are powered by a 30-kVA (30-kWl) variabille volltage tranisformer. Power is controllted with two saturable core reactors on the secondary side of the transformer. Uising a painit brushi, the four graphite electrodes, each $5 \mathrm{~cm}$ (2 in.) in diameter, were coatted writh three layers of sillicon carbide ( $\mathrm{SJC}$ ) to minimize oxidation during the ISV process. The botttom $15.2 \mathrm{~cm}(6 \mathrm{in}$.) of the ellectrodes rematined uncoated to prevent any intitial adherence of the moltten solit to the graphite ellectrodes, which may cause the eliectrodes to become hung up or frozen in the cooler, partialliy sollidified surfiace gilass. (a) of these uncoated portions of the eliectrodes, 10: $\mathrm{cm}$ (4 in.) was inserted into the soil prior to start up. (Subsequent Isv tiests have shown that the silc electrode coating resulted in the electrodes adhering to the colld cap; therefiore, the coating: is no longer recommended.)

The electrode fieed system and motor control valives for the system are shown in Figures 3 and 4 , respectively. The electrodes were spaced $30.5 \mathrm{~cm}$ (12 in.) apart. The feed system consists of a pneumatic motor and gripper for each electrode to provide control of the rate of electrode movement within the meit. With the gripper deactivated, the electrodes are free to move down with the advancing melt. By activating the gripper, the electrode can be held stationary or the motor can be used to ratise or lower the ellectrode as needed.

(a) Graphitte is not "wetted" or adhered to by the mollten gilass; Sic-coated graphite wil1 aillow the moltten gilass to adhere to the ellectrodes. 


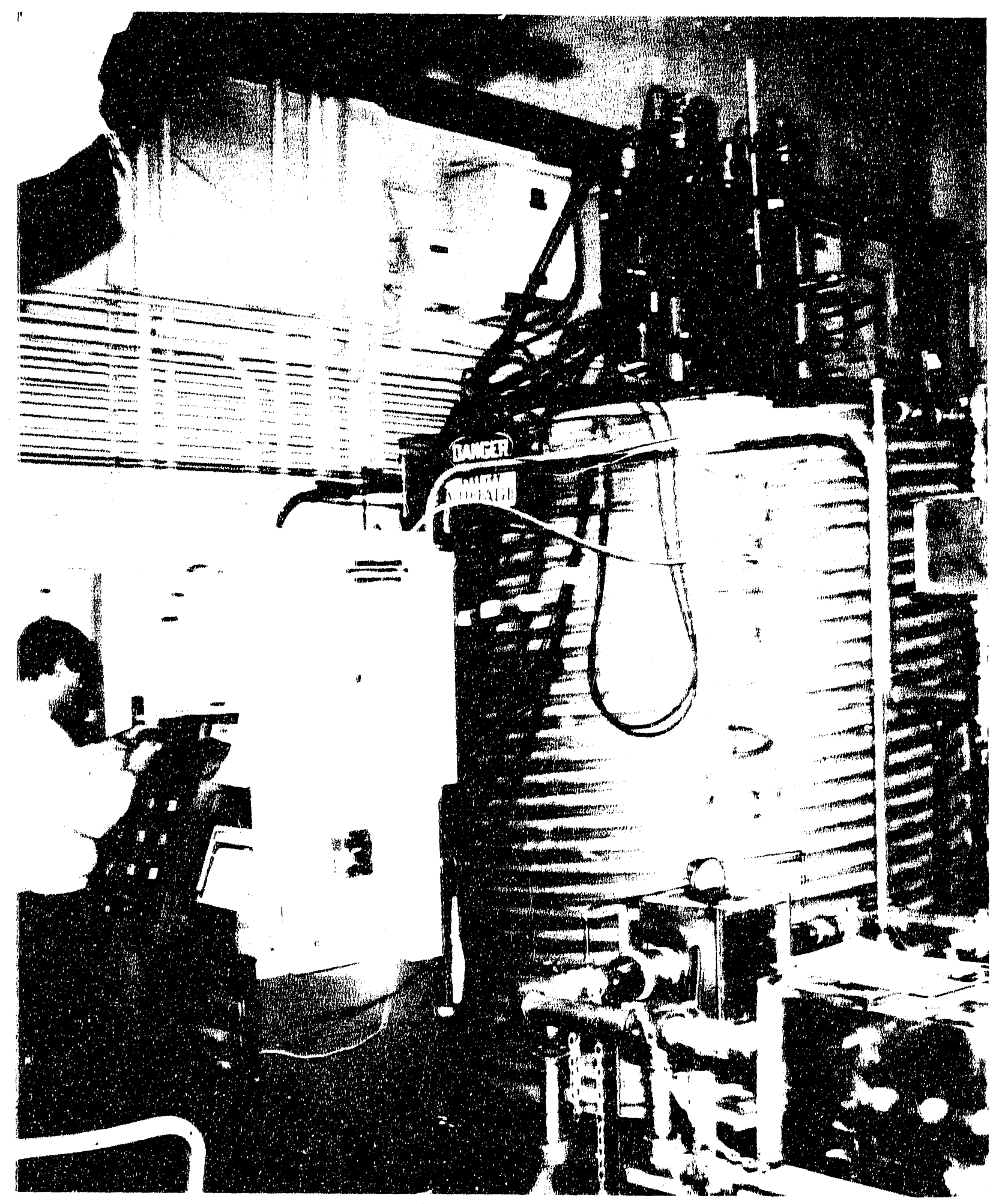

Flgure 2. Englineering-scale [SV Equipment. 


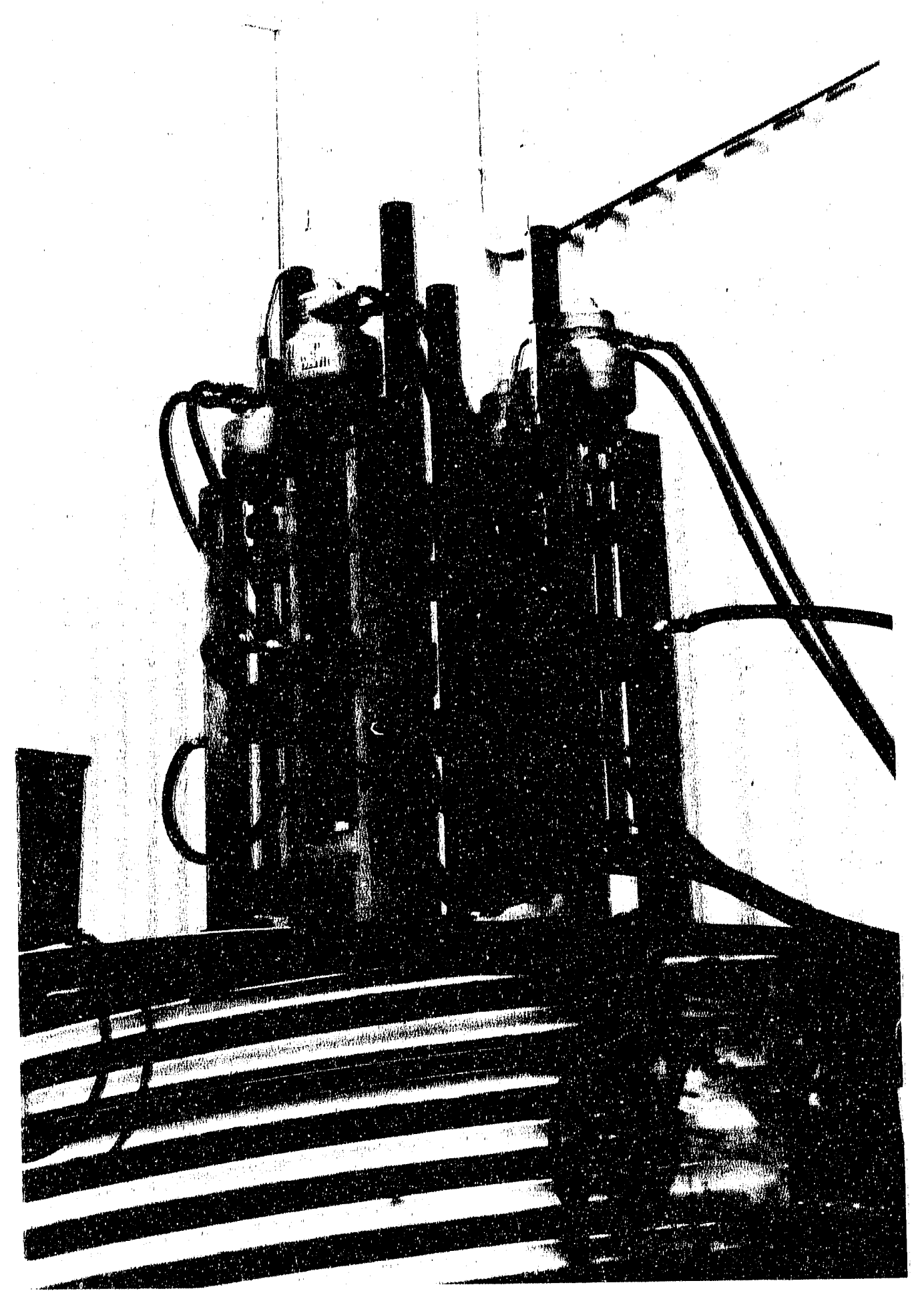

EIGURE 3. ISV Engineering-Scale Electrode Feed System 


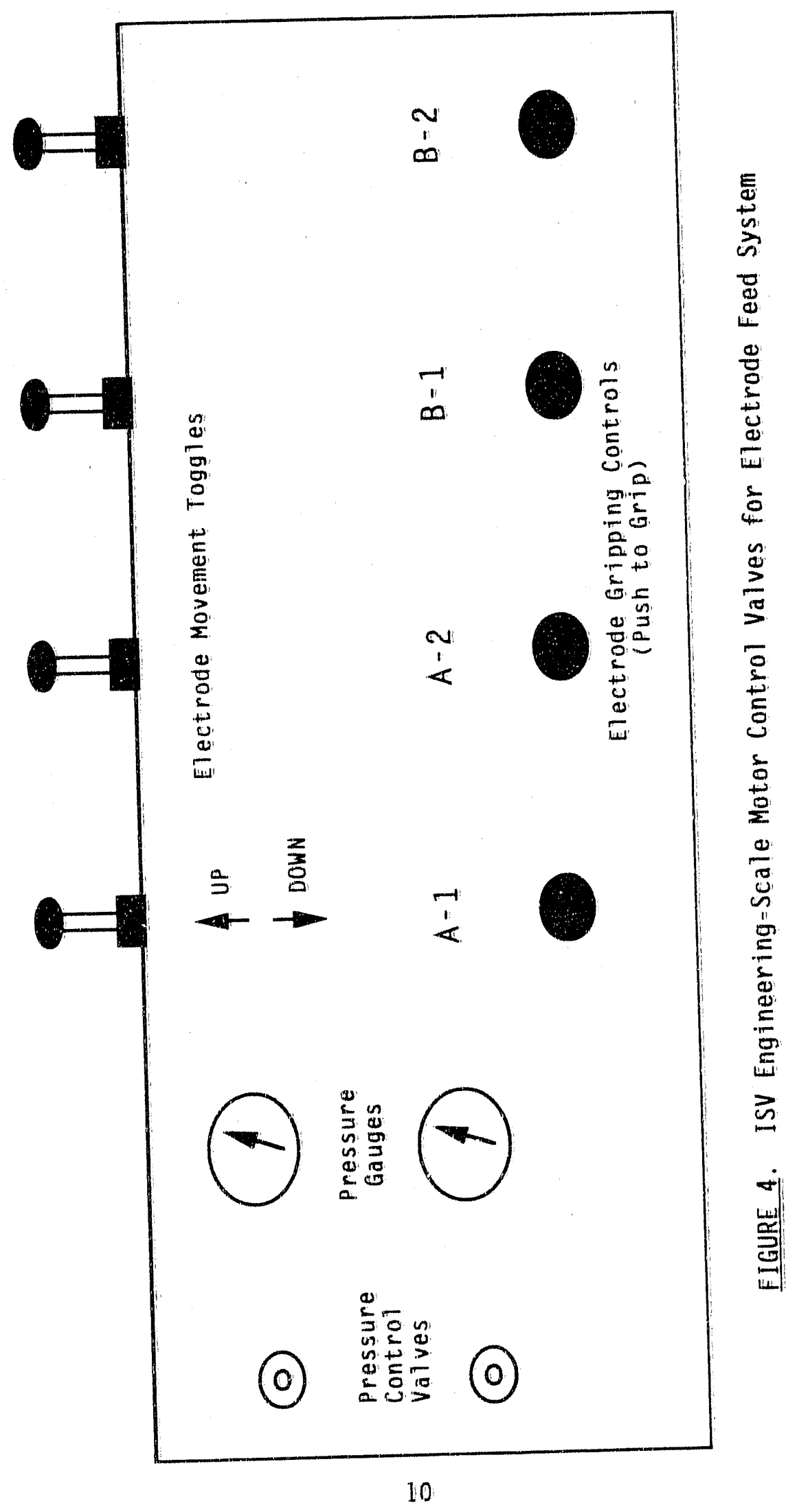


The ellectrode feed system is economicall and efficient because the graphitite electrodes are liess expensive tham the mollybdenum graphitte electrodes (Buelt et: ail. 1987)). Electrode empilacememit costs are allso reduced by eliminating the dritlling into contaminated sittes for prepillacement of the ellectrodes. Allso, thils sys.tem providles a mechamism to allieviate am ellectricall shorting condition in the mellt (Burellt and Farnsworth 1990)).

The englineering-scalle ISV offi-gas treatment system (shown in Figure 5) consisits of a condenser with knockowt pot, a heater, and a HEPA fillter. For this test, another HEPA filter was imstalled in the off-gas treatment system upistream from the condemser in order to evalluate the effectiveness of this fillter for removing CS. This HEPA filter. was manufactured by Flianders and had dirnens.ions of $30.5 \mathrm{~cm}(12 \mathrm{im}.) \times 30.5 \mathrm{~cm}(12 \mathrm{im}.) \times 30.5 \mathrm{~cm}(12 \mathrm{in.})$. The fillter had a removal efficiency of $99.97 \%$ at $260^{\circ} \mathrm{C}\left(500^{\circ} \mathrm{F}\right)$ for particuliate sized $0.3 \mu \mathrm{m}$ and 7 arger.

Throughout the test, the off gases from the vitrification process were s.ampiled thiroughout the test using a U.S. Environmental Protection Agency (EPA) referenced Modifified Method 5. (MM5) sample tratin: (40 CFR 60 Appendix A). The MM5 sampiling system is shown in figurre 6 . Off gases were sampled from the 5 - $\mathrm{cm}(2-\mathrm{in}$.$) off-gas 1$ ine through a $0.95 \mathrm{~cm}(0.375 \mathrm{in}$.) in diameter hiated probe assembilly. Particullate in the off glas was coll lected on a glass fiber fillter. The probe and glass fiber filter were matintained at approximately $130^{\prime \prime} \mathrm{C}\left(250^{\circ} \mathrm{F}\right)$ to prevent condensation on the filter. After extiting the fititer, the off gas entered a series of foulr impingers contained in an ice bath. The first impinger was empity, the second and third impingers contained deionized water, and the fourth impiniger contained silica gell. The impingers were used to remove condenstibles and solublie components from the off gas and to remove amy particulate that may have passed through the fiber filter. The silica gel dried the off gas before the gas reached the sampling system controll wnit. The moisture removed using the sitica gel was measured and used to determine totall water content. The sampling system control unit controlled the sampling rate and monitored the off-gas sampling vollume and the temperatures of the probe, filter, and impingers. 


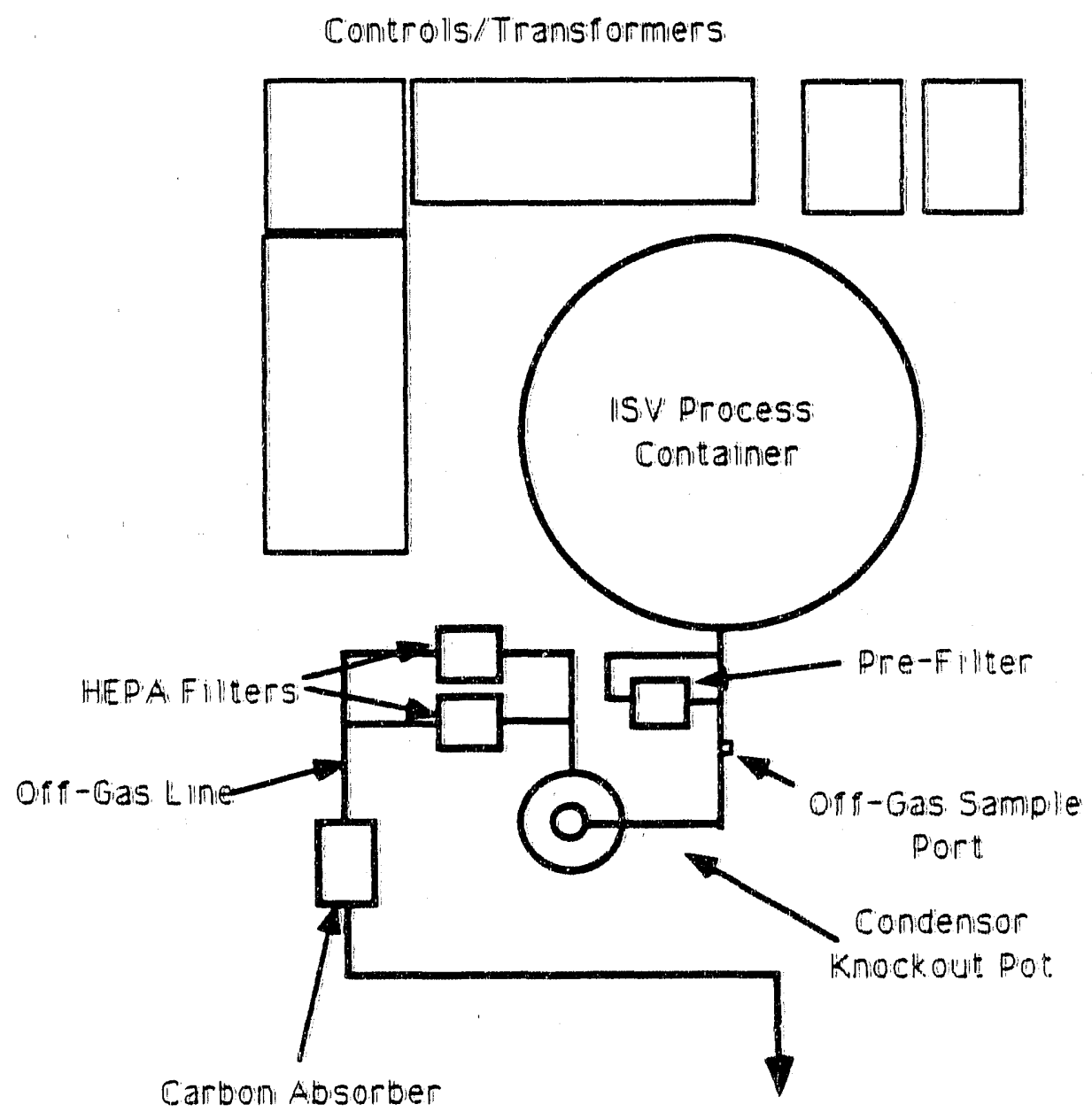

TO. POG Bllower

EIGURE 5. Engineering-Scale ISV Offf-Gas. Treatment Systo

The primary objective of the off-gas sampling was to verify the effectivemess of the HEPA filter for removing Cs from the off gas prior to the gases reaching the off-gas treatment system. Engimeering measures such as this filter will be necessary for liarge-scale ORNL trench remediall applications in order to minimize radiation exposures to workers from the ${ }^{137}$ Cs colllecting in the off-gas system. The HEPA filter was instatied with a vallved bypass to alliow the off-gas flow to be routed through the bypass line untin the melt approached the centeer of the cs zone, at which time the off-gas fliow was redirected through the HEPA fillter. Figure 5 illustrates the llocation of the prefilter and the sampling location. 


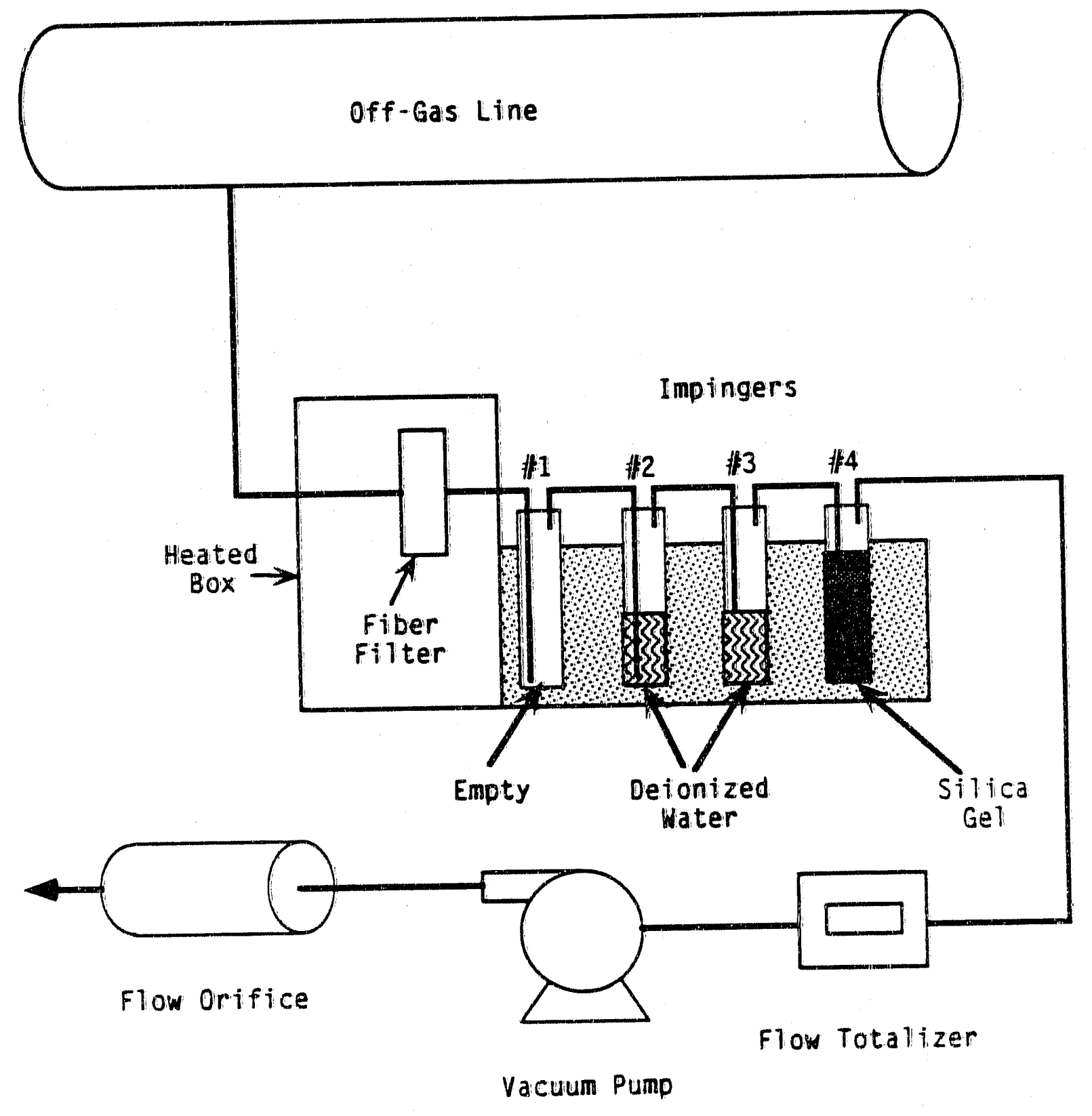

FLGURE 6. MM5 Sampling System

The MM5 sampling system was implemented after the start-up material (frrit/graphite starter path) had been consumed to eliminate loading the fiber filter with this particuliate material. Four distinct phases of sampling were performed. Phase 1 consisted of sampling the off gas from the start of the test until the thermocouple data indicated that the melt was approaching the 
top of the Cs-containing zone. At this point, the glass fiber filter was replaced with a new filter. Phase 2 consisted of sampling the off gas until the melt reached the upper half of the Cs-containing zone. The prefilter was not used during this phase. The fiber fitter again was replaced with a new filter, and the deionized water in the second and third impingers was replaced with new water. In Phase 3 , the off-gas flow was routed through the HEPA filter. This phase consisted of sampling the off gas until the melt reached the lower half of the Cs-containing zone. The fiber filter was replaced with a new filter. Phase 4 consisted of sampling the off gas as the melt proceeded bellow the Cs-containing zone without using the prefilter. During Phase 4 , power to the melt was fluctuated. Changing of the fiber filters allowed for a measurement of CS release as a function of time.

\section{TRENCH CONF IGURATIION}

The compositions of the ORNL solit and the limestone used in this test are provided in Table 1 . The soil and 1 imestone compositions were the same as those used in a laboratory study that evaluated the effect of varying soil and 1 imestone ratios, as well as the addition of a sodium flux on melt viscosity,

\section{TABLE 1. Compostion of ORNL. Soit and Limestore}

\begin{tabular}{|c|c|c|}
\hline \multirow[b]{2}{*}{ Oxide } & \multicolumn{2}{|c|}{ Oxide (wt\%) } \\
\hline & 5011 & Limestone \\
\hline $\mathrm{Al}_{2} \mathrm{O}_{3}$ & 16.3 & 1.7 \\
\hline $\mathrm{CaO}$ & 5.4 & 47.6 \\
\hline $\mathrm{Fe}_{2} \mathrm{O}_{3}$ & 5.6 & 0.7 \\
\hline$k_{2} 0$ & 4.1 & 1.5 \\
\hline MgO & 2.0 & 3.6 \\
\hline $\mathrm{MnO}_{2}$ & 0.1 & 0.03 \\
\hline $\mathrm{Na}_{2}, \mathrm{O}$ & 1.3 & 0.5 \\
\hline $\mathrm{SiO}_{2}$ & 55.6 & 5.3 \\
\hline sro & 0.02 & 0.05 \\
\hline $\mathrm{TiO}_{2}$ & 0.70 & $\cdots$ \\
\hline Total & 91.12 & 60.98 \\
\hline
\end{tabular}


electrical conductivity, and Cs volatility (Shade and Piepel 1990). The trench for the engineering-scale test was composed of 7 imestone with cesium carbonate added within the voids of the limestone. A small amount of sodium carbonate was also added to the limestone trench region to simulate the $\mathrm{Na}$ content in the ORNL trenches and to evaluate the effect on Cs volatility in the presence of increased $\mathrm{Na}$ content. The rewaining processed soit was from ORNL and was representative of the soil encountered at that site.

The trench configuration is shown in Figure 7 . Oak Ridge soil was placed in the center of the container in a 91.4-cm (36-in.) circle starting at. the $91.4-\mathrm{cm}(35-\mathrm{in}$.$) depth. The limestone trench was constructed between the$ $20.3-\mathrm{cm}(8-\mathrm{in}$.$) to 45.7-\mathrm{cm}(18-\mathrm{in}$.$) depth and contained 7.0 \mathrm{~kg}$ of $\mathrm{Na}_{2} \mathrm{CO}_{3}$ and $25.9 \mathrm{~kg}$ of limestone. At the $35.6 \mathrm{-cm}(14-\mathrm{in})$ to $45.7-\mathrm{cm}(18-\mathrm{in}$.$) depth,$ $1220 \mathrm{~g}$ of cesium carbonate was mixed with the limestone and $\mathrm{Na}_{2} \mathrm{CO}_{3}$ in the area of the trench between the electrodes. The Cs was postitioned in the trench so that all the $C_{s}$ would be consumed during the vitrification process. Type $k$ thermocouples were located on the top, bottom, and center of the Cs area to monitor melt progress through this area. The limestone trench pictured in Figure 8 measured $43.2 \mathrm{~cm}(17 \mathrm{in.})$ long by $25.4 \mathrm{~cm}(10 \mathrm{in}$.$) deep with the area$ external to the trench filled with Oak Ridge soil out to the $91.4 \mathrm{~cm}(36 \mathrm{in}$. diameter. Hanford soil was placed in the engineering-scale container in areas that would not be vitrified.

A starter path $2.5 \mathrm{~cm}(1 \mathrm{in}.) \times 2.5 \mathrm{~cm}$ (l in.) consisting of graphite and glass frit was placed between the electrodes in an " $X$ " and square pattern. A $2.5-\mathrm{cm}$ (1-in.) pure graphite flake layer was placed around each electrode, and then a $2.5-\mathrm{cm}(1-\mathrm{in}$.$) layer of graphite and glass frit was placed on tap$ of the pure graphite flake. Sand was blended with the ORNL soil that filled the top $5 \mathrm{~cm}(4 \mathrm{in}$.) of the trench in order to eliminate the void space in the coarse ORNL soir. This ensured that continuity of the electrode path would not be disturbed by the molten soil flowing into the voids during the initial start-up period. The area between the electrodes was covered with $2.5 \mathrm{~cm}$ (l in.) of soil and $2.5 \mathrm{~cm}(1 \mathrm{in.})$ of alumino-silicate insulating blanket to minimize heat surface loss and promote melt surface subsidence during processing. A gap in the insulation around each electrode provided a gas vent. 


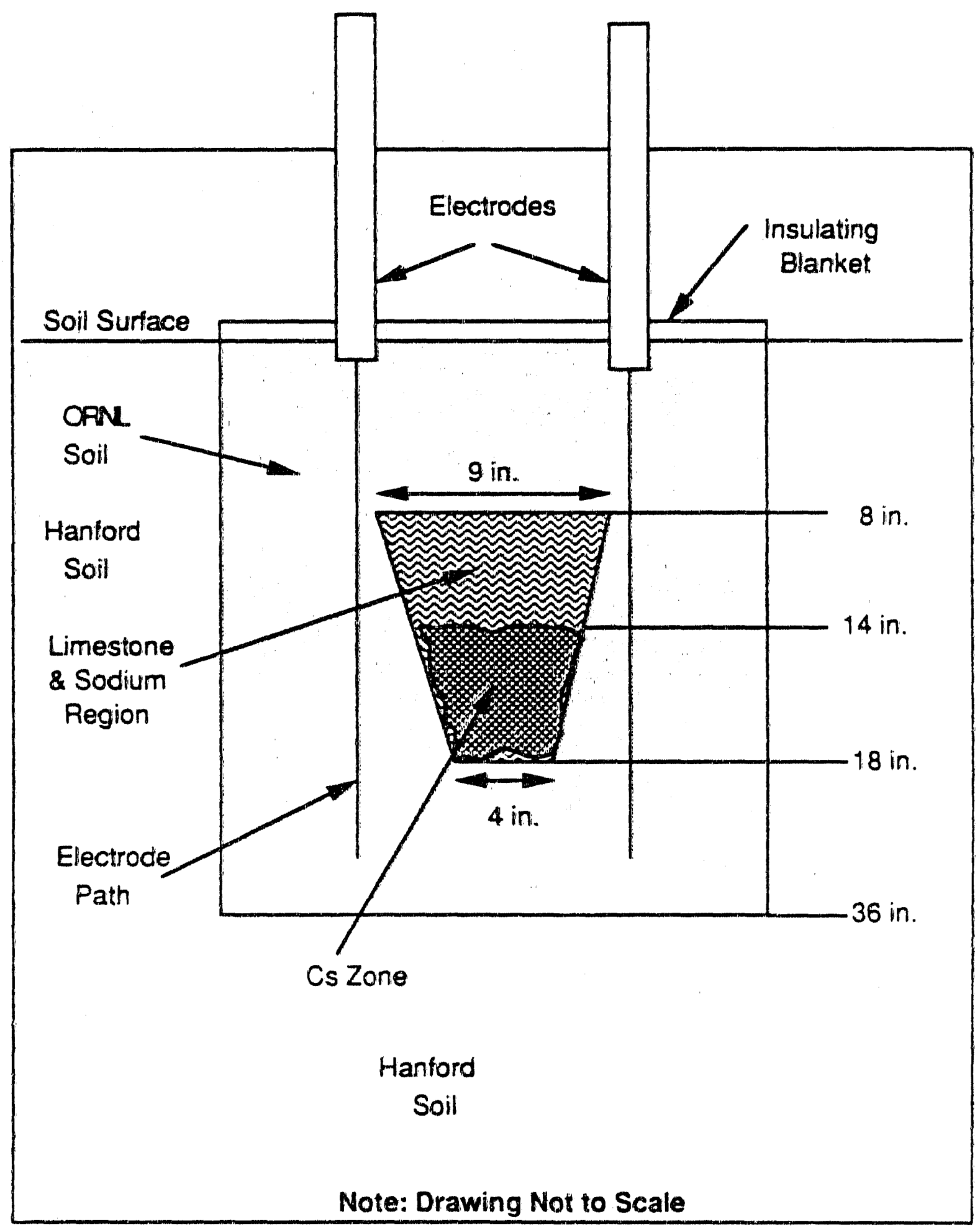

FIGURE 7. ORNL Engineering-Scale Trench Configuration 


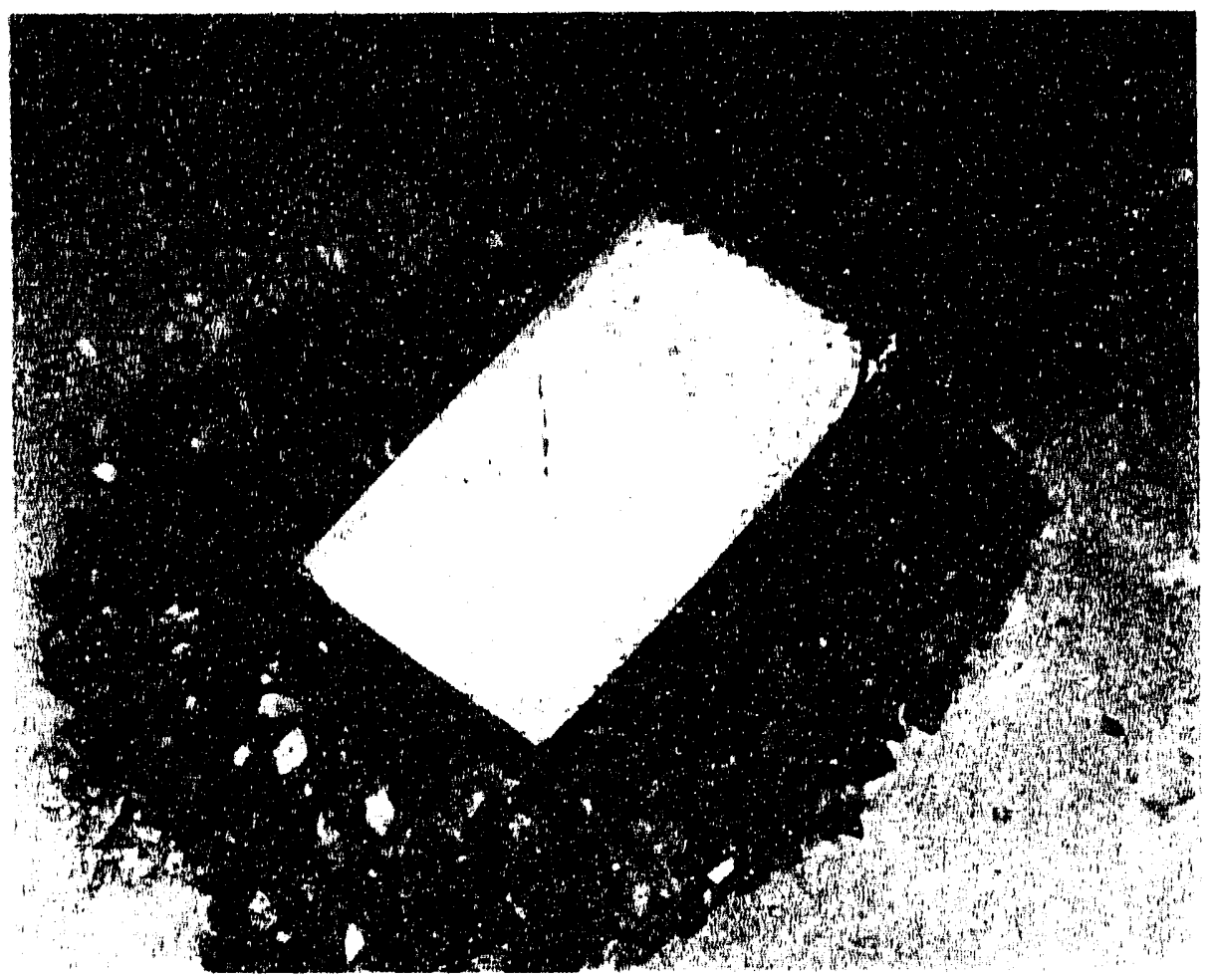

F[GURE 8. Engineering Scale Limestone Trench Before Vitrification

THERMAL MOULTORING ANO PRESSURE INSTRUMENTATLON

Type $x$ thermocouples were used to monitar the depth of the witriffidtion process. These thermocouples were located in the center of the witrification zone. The first thermocouple was placed $5 \mathrm{~cm}$ (? in.) below the soti surface, and subsequent thermocouples were placed every $5 \mathrm{~cm}(2 \mathrm{in.}$. The last thermo couple was located at a depth of $61 \mathrm{~cm}(24 \mathrm{~m}$.$) . The thermomoln measure$ ments were recorded on a strip chart recorder located in the englnereng coln control console.

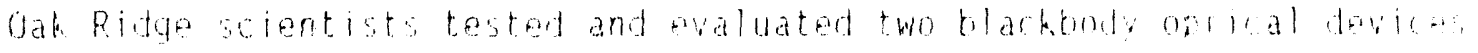
and six Type thermocouples with varying frotective odtings and hod the The blackeody optical devices are showe in figures 9 and 10 . The six lype thermocouples and their assoclated protective cad ings and sheath are li ted in Table?. The sheathing protected the therrocouples from corosion and on dation, and the sheathing and thermocouples wers avaluatod in conbination to 
obtain performance data. These thermal measuring systems were monitored on a real-time basis using a separate data acquisition system. These Type $C$ thermocouples were located at a depth of $16 \mathrm{in}$. The placement of the thermocouples and blackbody optical devices is shown in Figures 11 and 12 . The two blackbody optical devices were at a depth of 18 to $21 \mathrm{in}$.

Two pressure transducers were installed in the engineering-scale container. These transducers were manufactured by Omega and had a range of 0 to $50 \mathrm{psi}$ with an accuracy of $\pm 1.0 \mathrm{psi}$. The transducers were buried in the soil and connected with 0.25 -in. tubing to digital displays for monitoring. One was placed $25.4 \mathrm{~cm}(10 \mathrm{in}$.$) below the soil surface near the center of the vit-$ rification area, and the other was placed $50.8 \mathrm{~cm}(20 \mathrm{in.})$ below the soil surface near the center of the vitrification area. These pressure transducers were installed to monitor pressure gradients due to moisture ahead of the advancing melt. 


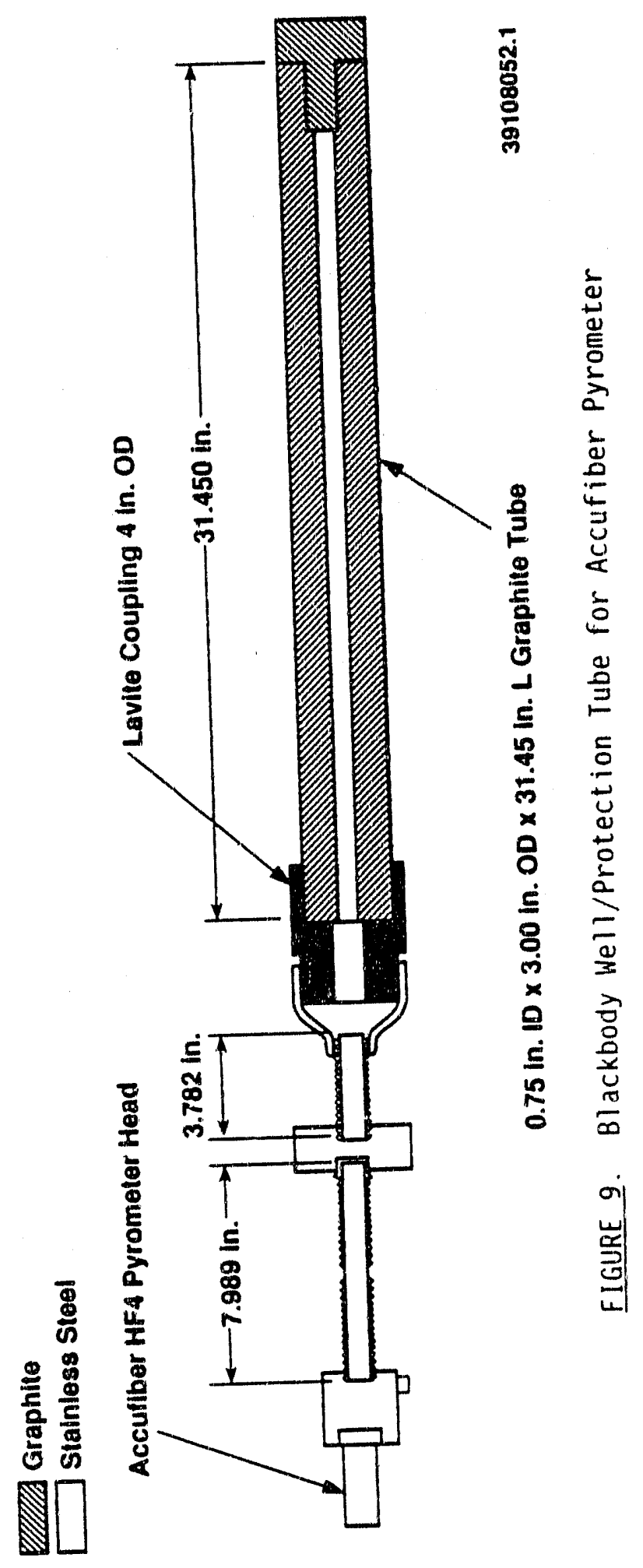




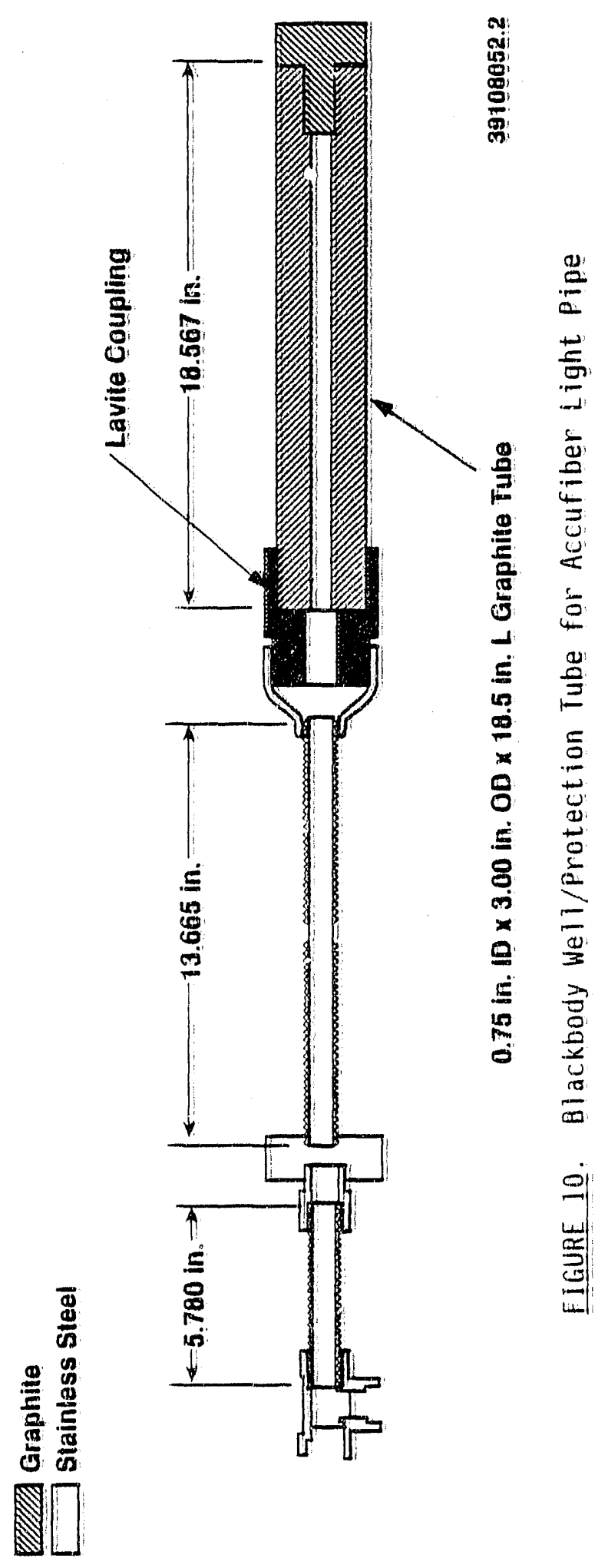


TABLE 2. ORNL Type C Thermocoupile Protiection

Thermocoupilie: Number

1

2

3

4

5

6

\section{Proitection Description}

0.25-in. allumina tube iniside a 01.5-inı. allumina tube purged with Ar

All coatting: on thermocoupile inside a $6.5-\mathrm{in}$. allumina tube

0.25-in. allumina tube inside a 1-iin. graphitite tube purged with Ar

0.5-in. allumina tube

Rustolleum All coatting on thermocouple inside a 1 -im. graphitie tube

0. 25-in. alumina tube purged with Ar

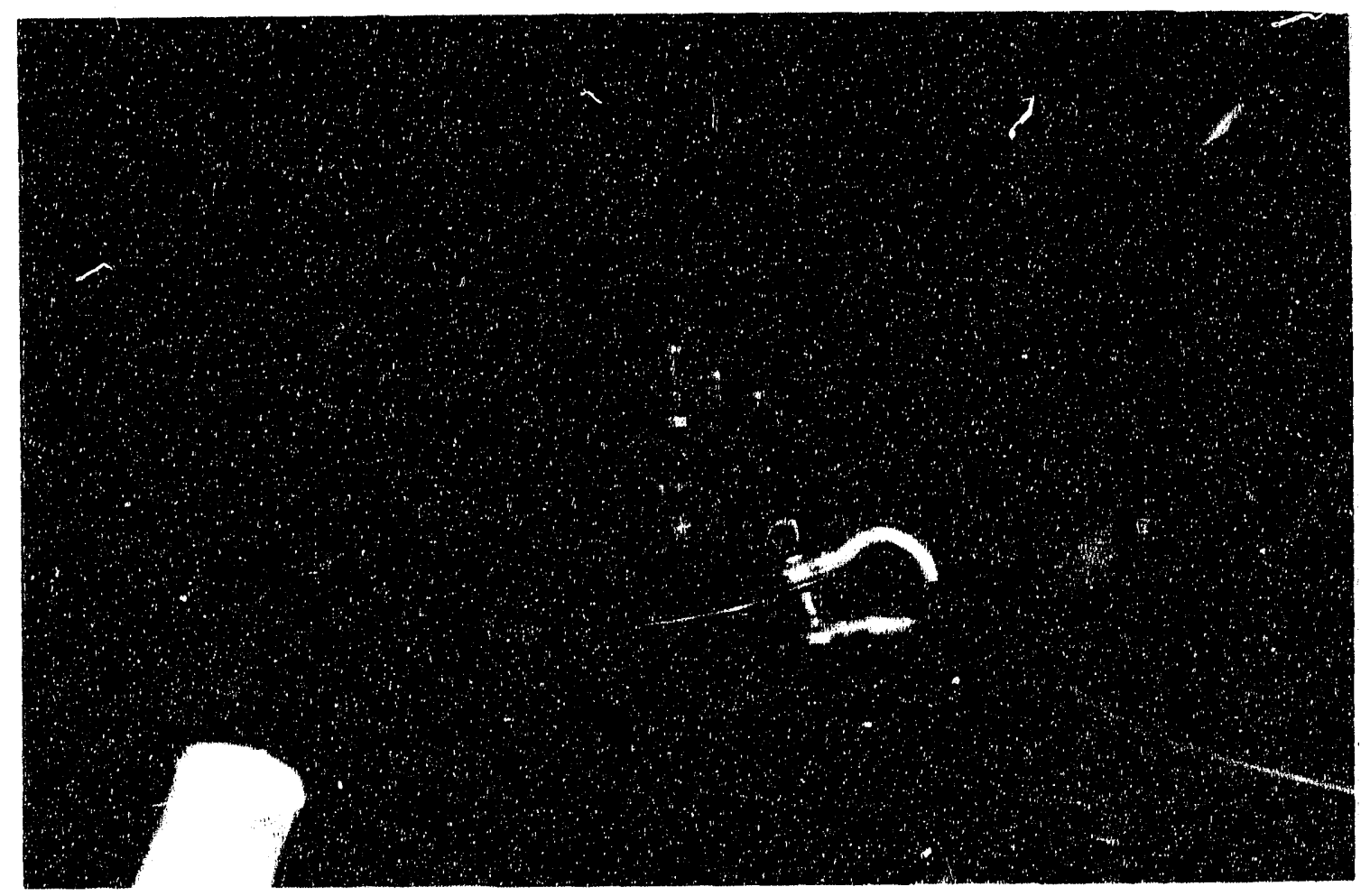

FIGURE 11. Placement of Thermocouples 


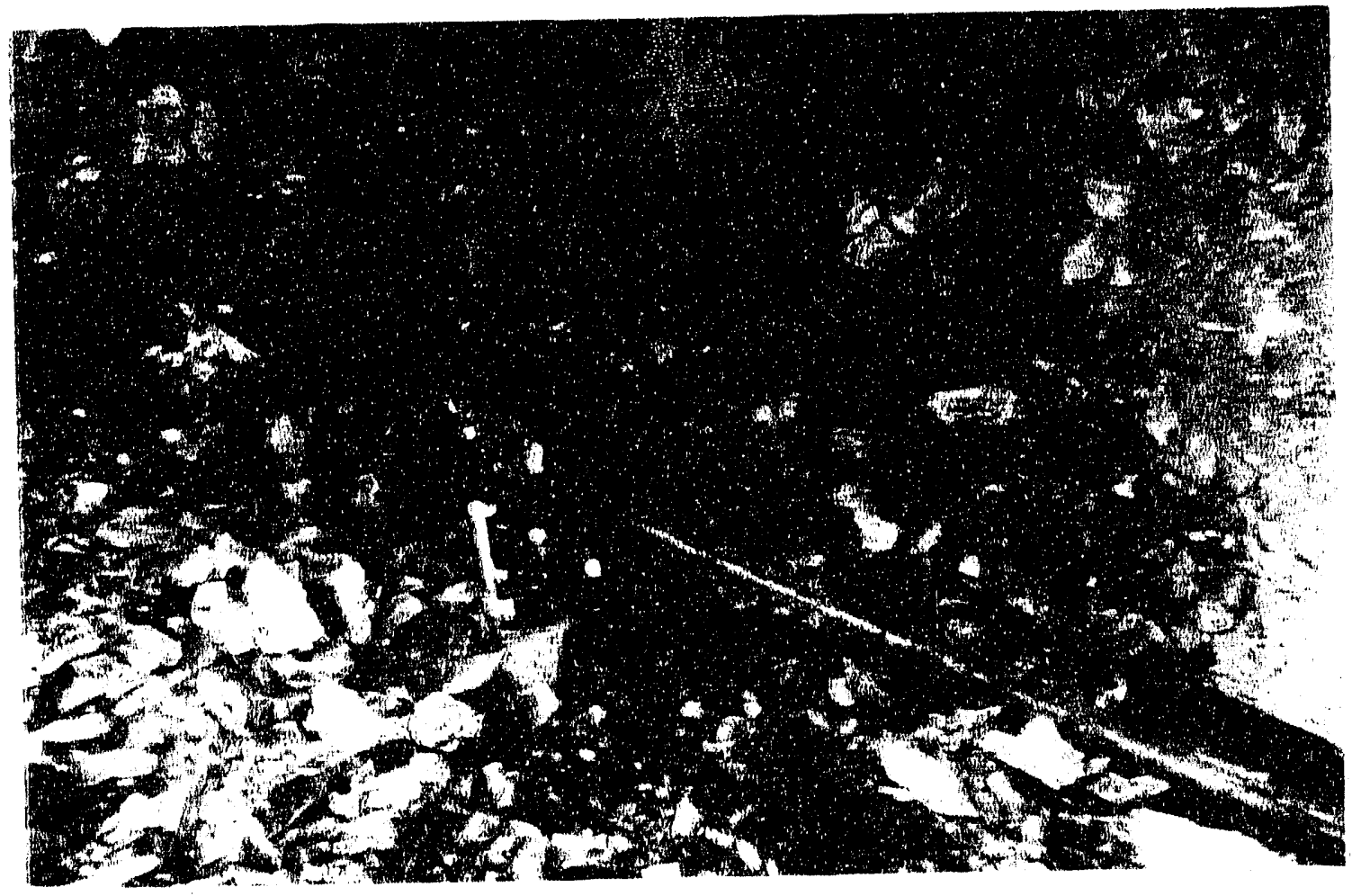

F[GUPE 12. Placement of Blackbody optical Devices 


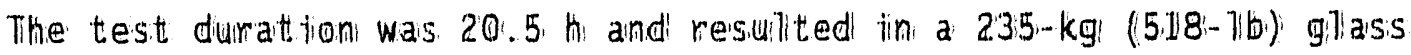
billock thatt measured $511 \mathrm{~cm}(20)$ in.) ) wide: om botth sides and $56 \mathrm{~cm}$ (22 in.) deep. The bilock produced is shown tim Figure 13. The resullt ing gilass was composed off $87 \%$, sorill and $13 \%$. 7 timestone. The bilock had a large surface substidence, approximattelly: $4.0 \%$ of the bilock size that measured $28 \mathrm{~cm}$ (11 i in.) deep from the orriglfinall surface grade. The substidence was creatted by the densiffication of the solit and decompositition of the litimestone trench. The subsidence porttion of the block was included tim the overalli dlimeristionis of the bilock due to the signilficant amounit of gillass. that formed the wallls: of the subsidence cavity. A small hammer. and wire brus.h were used to remove nonvittriffied matterial frrom the bilock to achieve an accurate weight off the gilass prodiced. The wailis off the

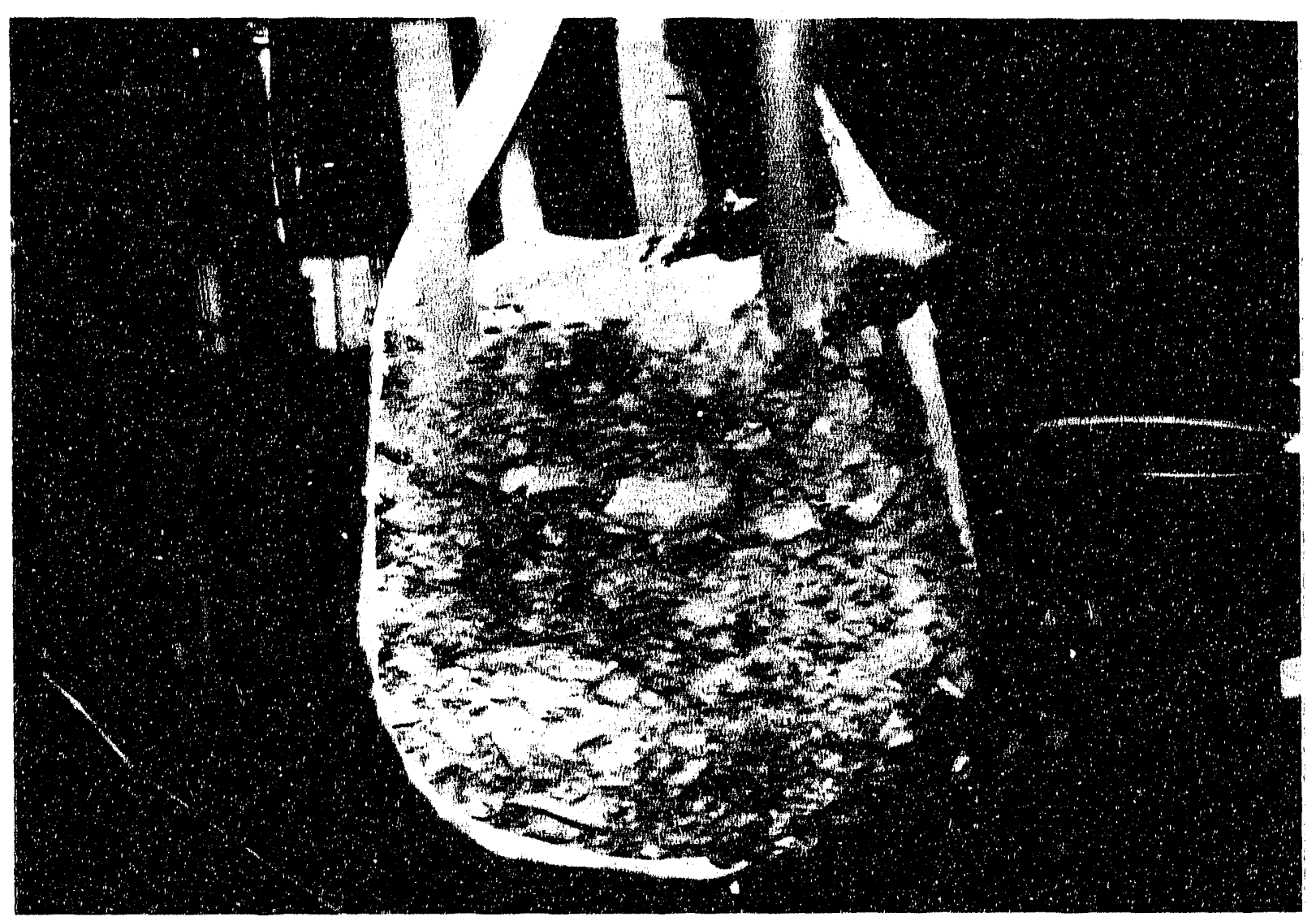

EIGURE 13. ISV B Block Produced During Engtineering-Scalle Test 
subsidence cavity, which weighed $25 \mathrm{~kg}_{\text {, }}$ were removed from the block. The block without the walls is shown in Figure 14. Earlier tests using electrode feeding on soilis with high metal content have produced bllocks with near verticall wallis and minimal lateral growth (Farnsworth, Oma, and Bigelow 1990), possibly attributable to the metal pooling and corresponding power concentration at the bottom of the melt. With ORNL soilis and trench configuration, the electrode feed system did not affect the melt shape as the resulting tear-drop melt shape was typical of ISV melts.

\section{MELT DEPTH VERSUS TIME}

The Type $k$ thermocouple measurements obtained from the center of the melt were used to assess the melt depth versus time. When the glass reached the depth at which the thermocouple was located, these readings went offscale. The melt depth versus time is shown in Figure 15 . During the inttial

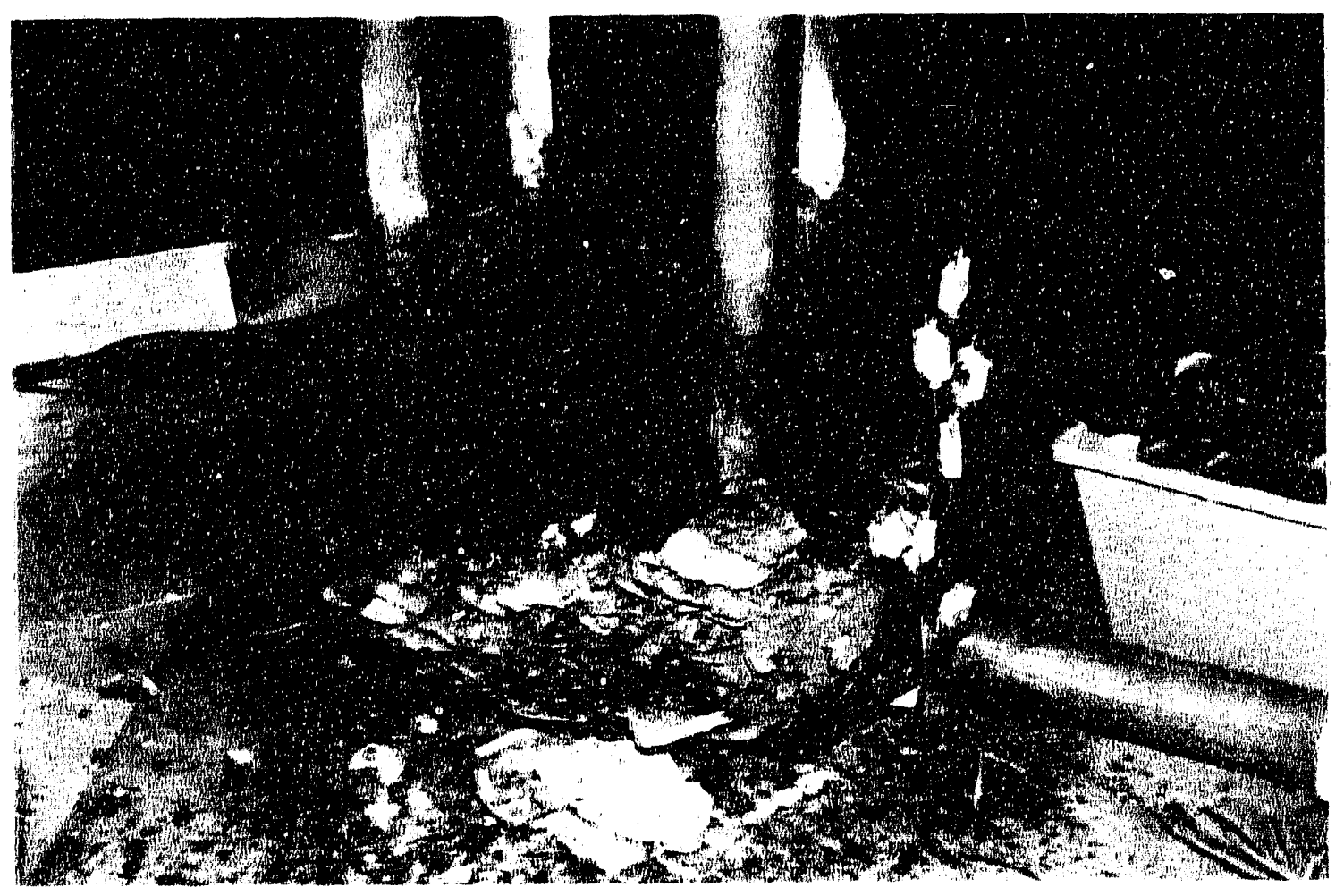

FIGURE 14. GTass Block After WaT1s Were Removed 


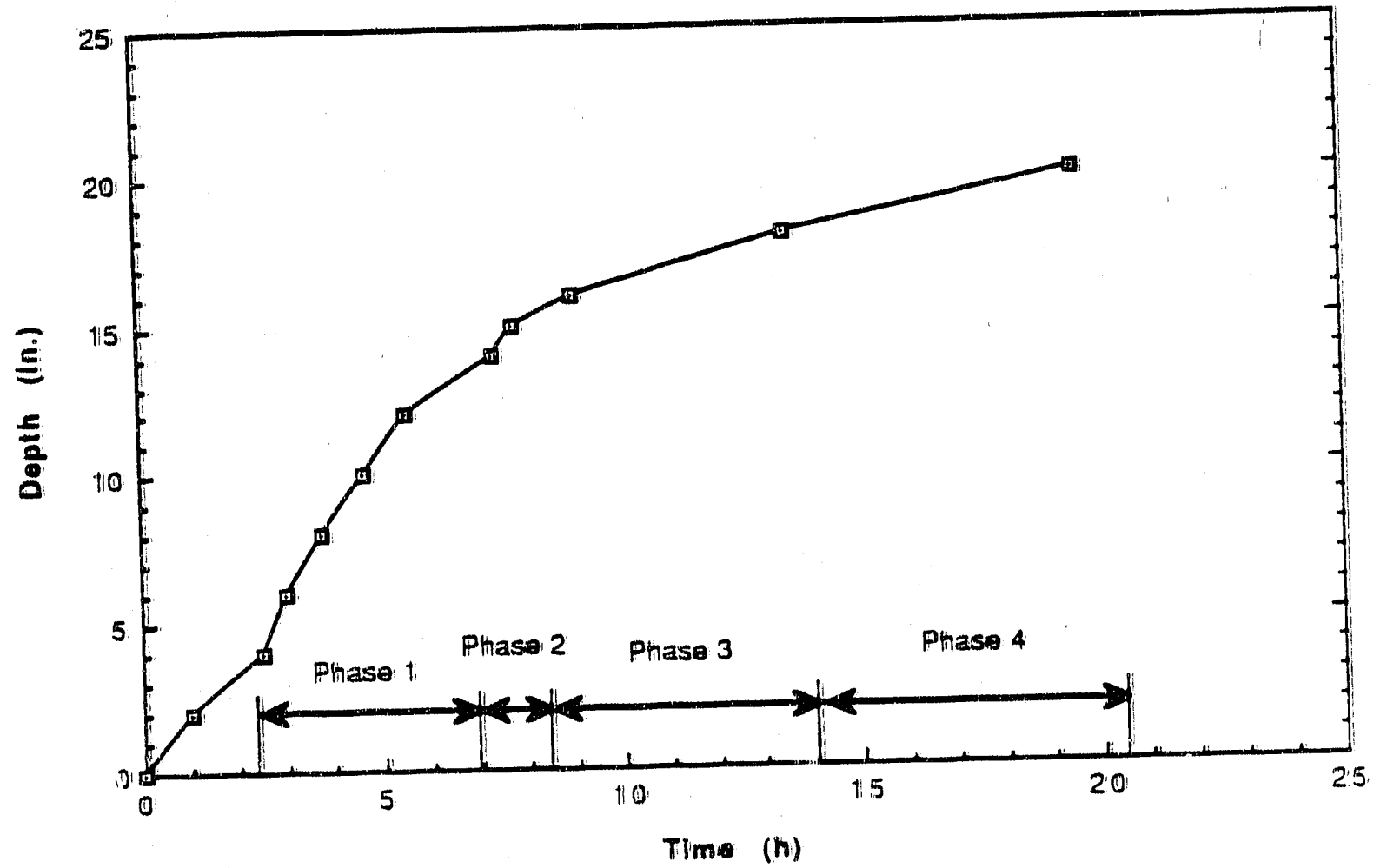

FIGURE 15. Mellt Depth Versus Time as Determined by Type $k$ Thermocouples

4.6. hi of the test, the melt progressed downward fairly rapidily at a rate of approximatelly $2.6 \mathrm{in.} / \mathrm{h}$. As the inelit proceeded, the melt rate slowed to approximatelly $0.35 \mathrm{im} . / \mathrm{h}$. The inclusion of 1 imestone in the melt resulted in a decrease in the melit temperature, an increase in electrical conductivity, and a decrease in viscosity; these changes resulted in a slightiy increased melit rate (Shade and Piepel 1990)). As the melt proceeded past the limestone trenchi, soit was incorporated into the mellt and resulted in an increase in the melt temperature, a slight decease in electrical conductivity, and an increase in viscosity. Therefore, the melt depth rate slightly decreased. In Phase 4 of this test, power to the melt was reduced to evaliuate the effect of power reduction on the melt temperature. The reduction in power slowed down the meltt rate. Power was increased at the end of the test to observe a corresponding increase in melt temperature and melt rate. (The phases are described in the test description section of this report). 


\section{Mellt Processing Temperature}

The melt temperature was monitored continuously during the test. The pilot of the silx Type $C$ thermocouples is provided in Figure 16. Thermocouple \#5 was not in the melt region during a majority of the tert operations and should be disregarded. The temperature data showed that the melt temperature ranged from $1300^{\circ}$ to $1400^{\circ} \mathrm{C}$ during this test. This corresponded closely with the $1330^{\circ} \mathrm{C}$ temperature measured in the laboratory for a melt viscosity of 100 poise (TIOOP). An ISV melt typicallly operates near the TIOOP temperature

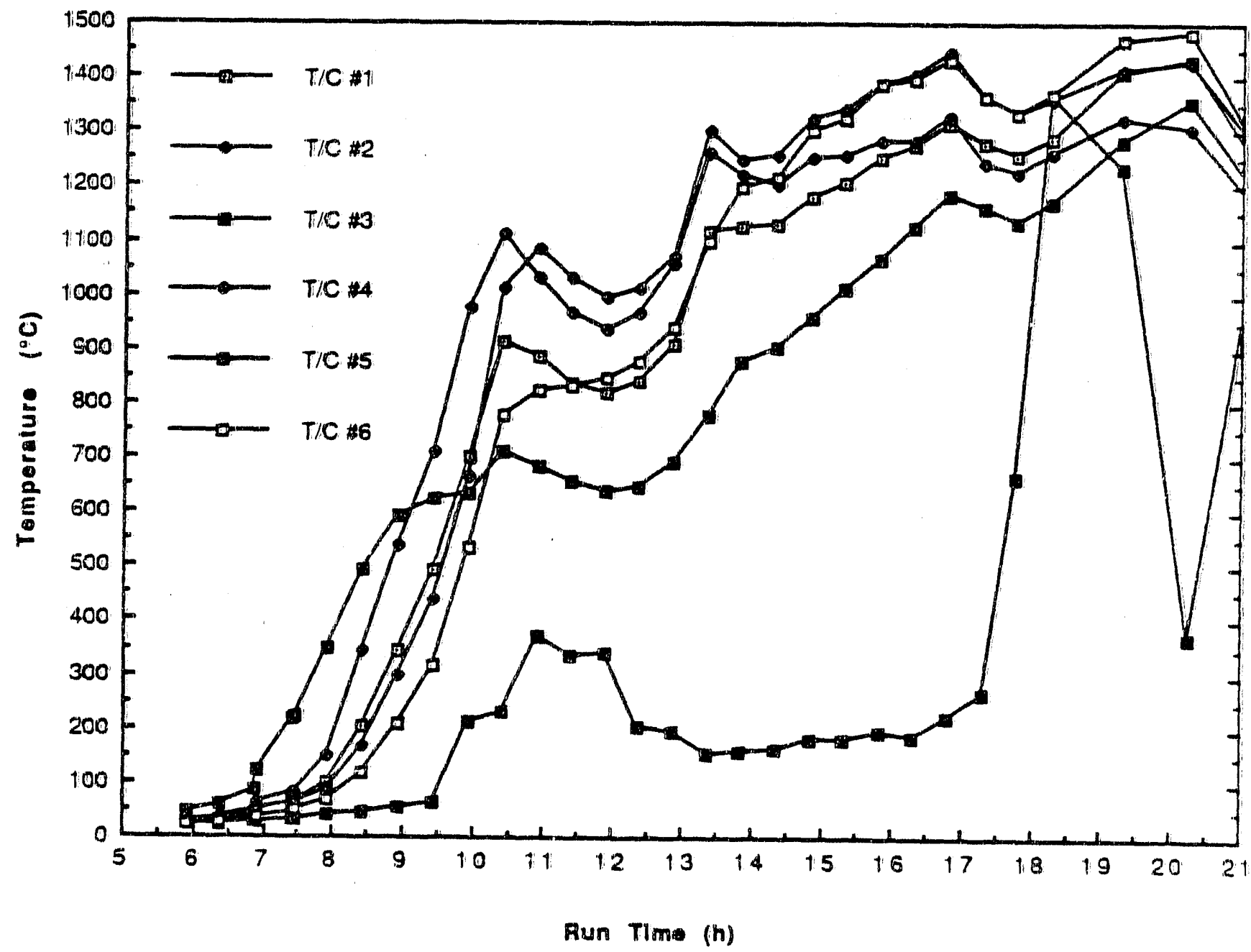

EIGURE 16. Type C Thermocouple Data 
(Buellt et all. 1987): Alll of the Type C thermocouplle protection survived the conditions of the $15 \mathrm{~V}$ melt. The graphite tubes from the pyrometers were srignificaintly oxidized.

\section{Electricall Power}

A represemtation of the electrical power used during this test is shown in Figure 17. The totall emergy consumed for the test was $335 \mathrm{kWh}$. This resulted in an energy-to-mass ratio of $1.4 \mathrm{kWh} / \mathrm{kg}$ of soill and 1 imestone that were vitrified. The mass of soill and 7 imestone fincorporated into the block

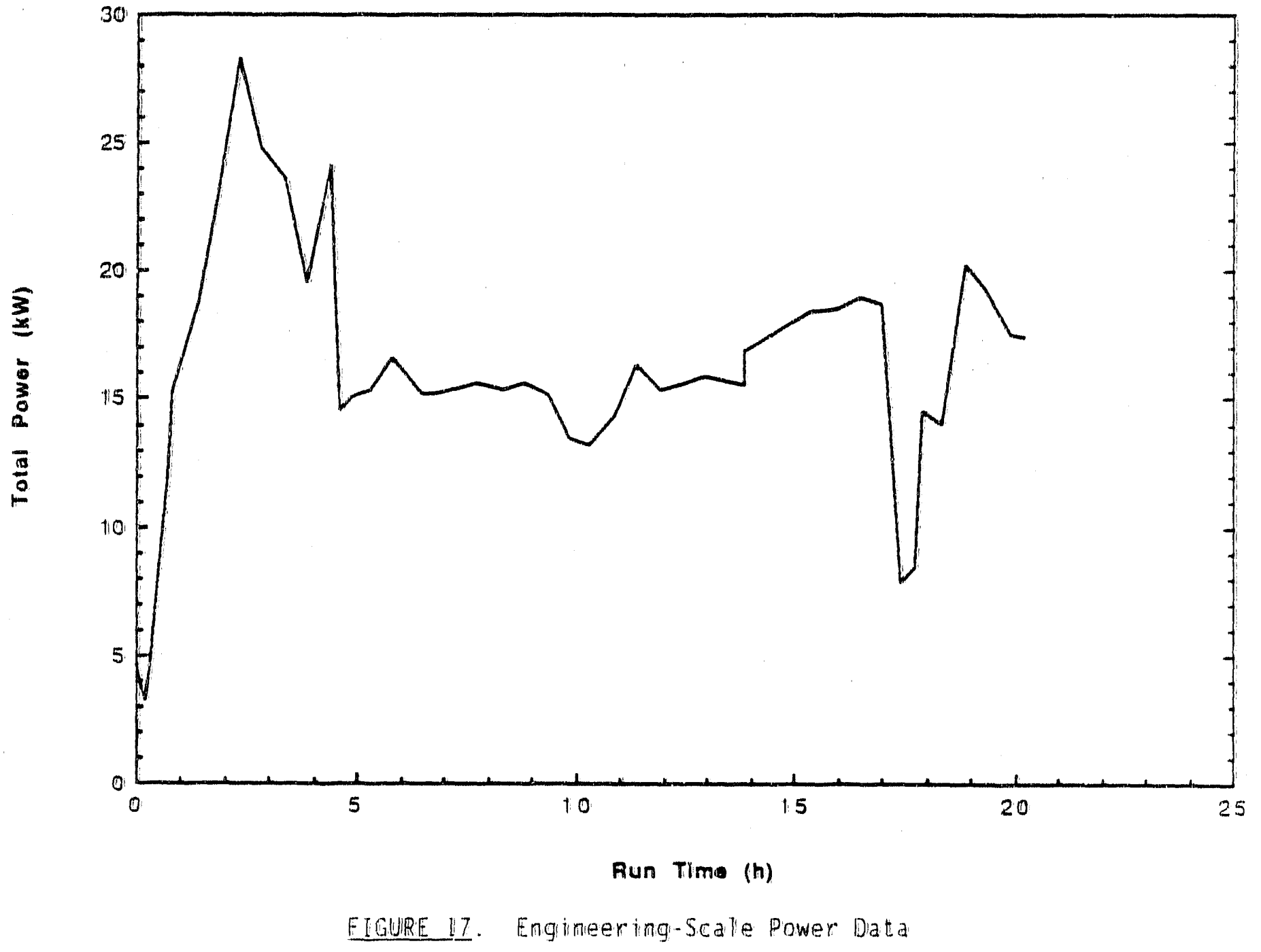


weighed approximattely $245 \mathrm{~kg}$. The voltage and amps supplied to the inelt are shown in Figure 18, and the calcullated electiricall resistance is shown in Figure 19 .

After 16.9 h of operation, the power to the melt was fluctuated to obtain data on the dynamic effects of power reductions on melt temperature. These corresponding data on reduced melt temperature and increased molten soll viscosity may benefit ORNL ISV remediation of the radioactive trenches. The reduced melt temperature may reduce the Cs volatility. The Cs-contaminated zone is onily a smal1 section of the vertical profile of the trench and is also. at the bottom of the trench. If the ISV melting process was operated at reduced power levels during the period of time that the melt is passing through the contaminated zone, the reduced melt temperature may emhance the $C_{s}$ retemtion within the melt by reducing vapor pressure and its mechanisms of release, such as convective tramsport within the melt and diffusion to the

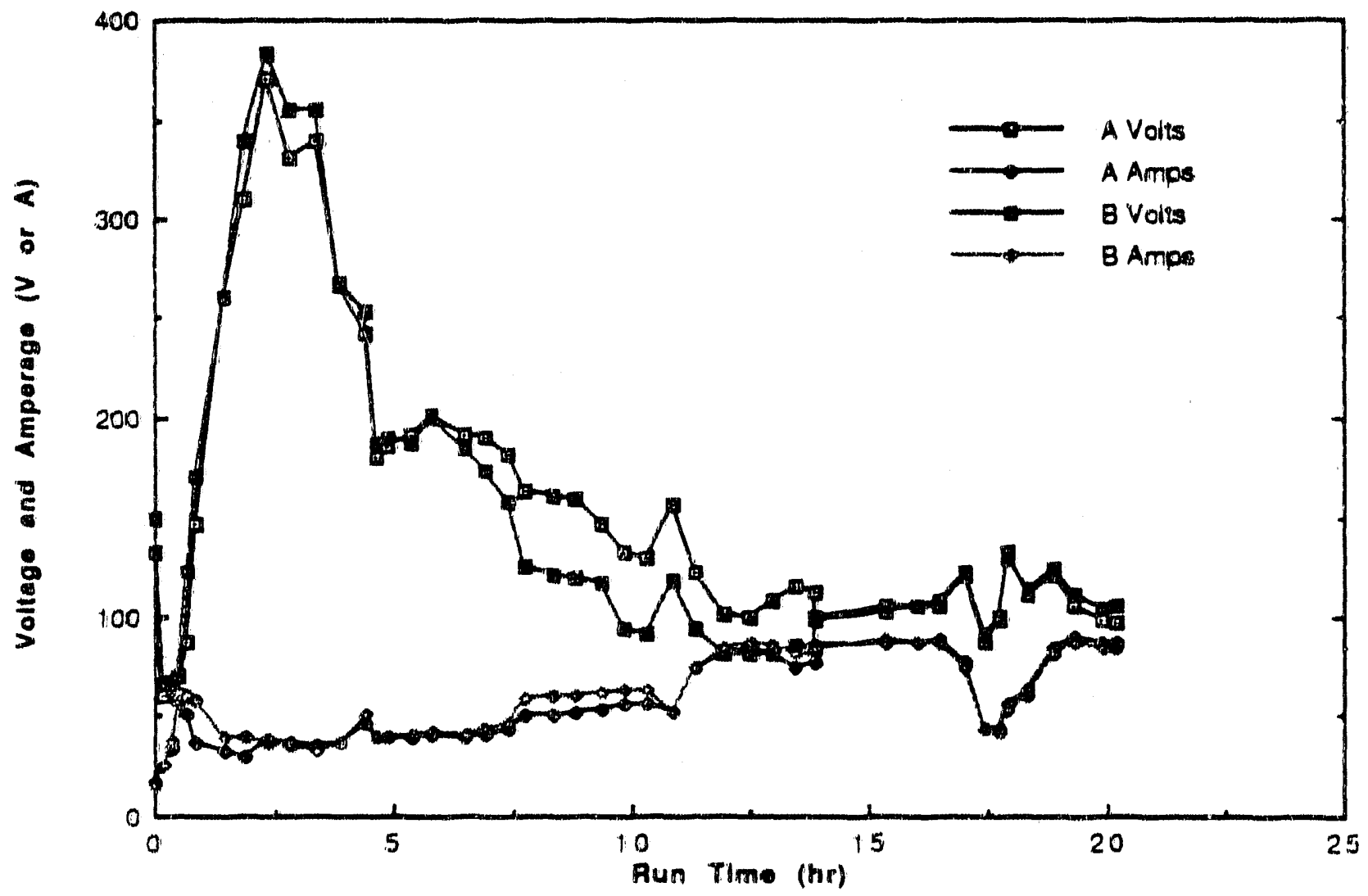

FlCURE 18. Voltage and Amperage Data for Engimeering-Scale Test 


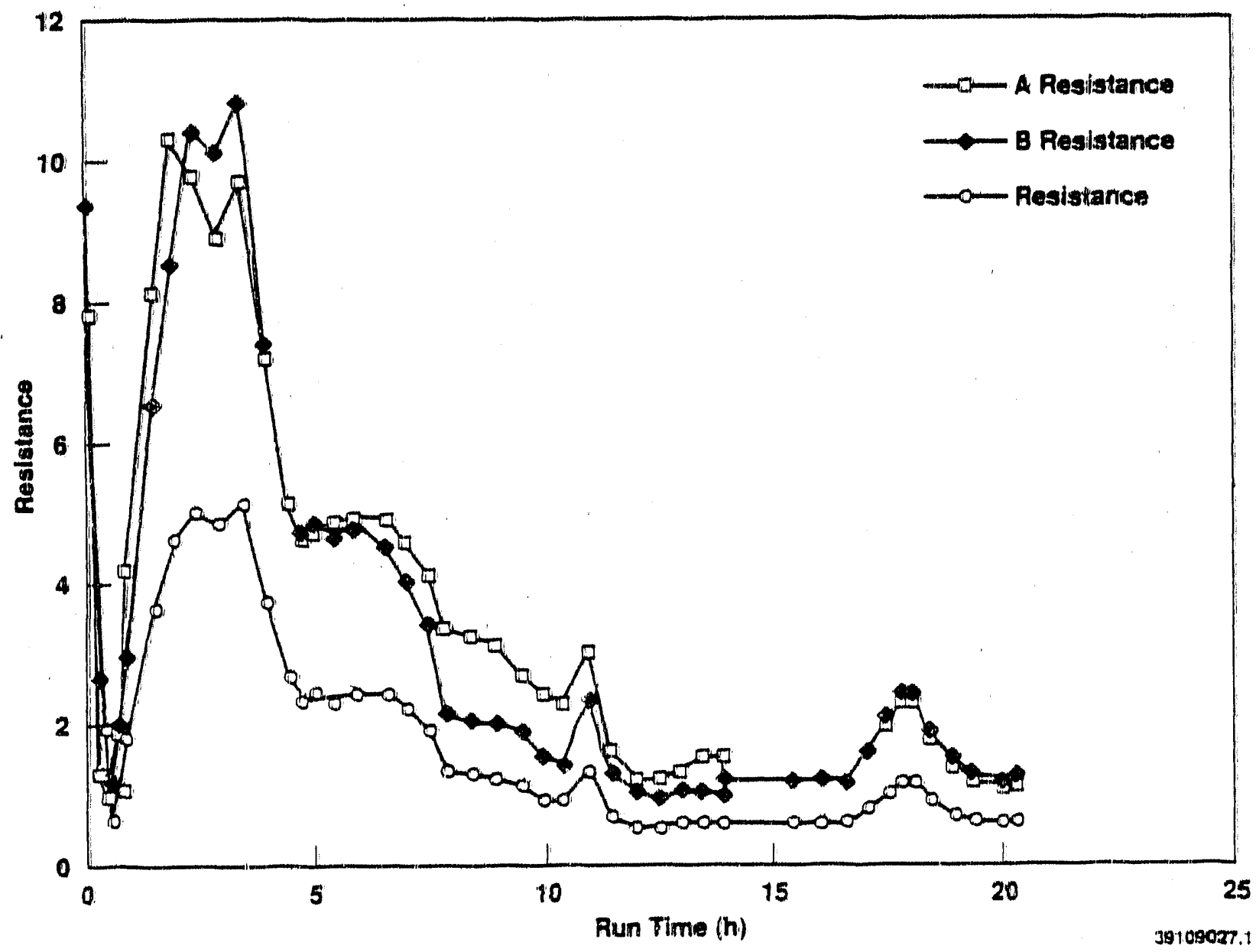

FIGURE 19. Calculated Electrical Resistance During the Engineering-Scale Test

melt surface where it may become entrained into the off-gas stream. The reduce melt temperature would enhance the formation of a more impenetrable cold cap to reduce the release of $C s$ to the off-gas system.

The effects of power fluctuation on the melt temperature are illustrated in Figure 20. The melt temperature was monitored with the Type $C$ thermocouples. Thermocouple $\$ 5$ was not in the melt region during the power fluctuation period and therefore, it is not included in figure 20 . The left side of the graph shows a reduction in melt temperature of approximately $200^{\circ} \mathrm{C}$ when the power was reduced from $100 \%$ to $50 \%$ (from 18 to $9 \mathrm{kw}$ ). The center of the graph indicates the effect of increasing the power from $50 \%$ to $75 \%$ (from 9 to 


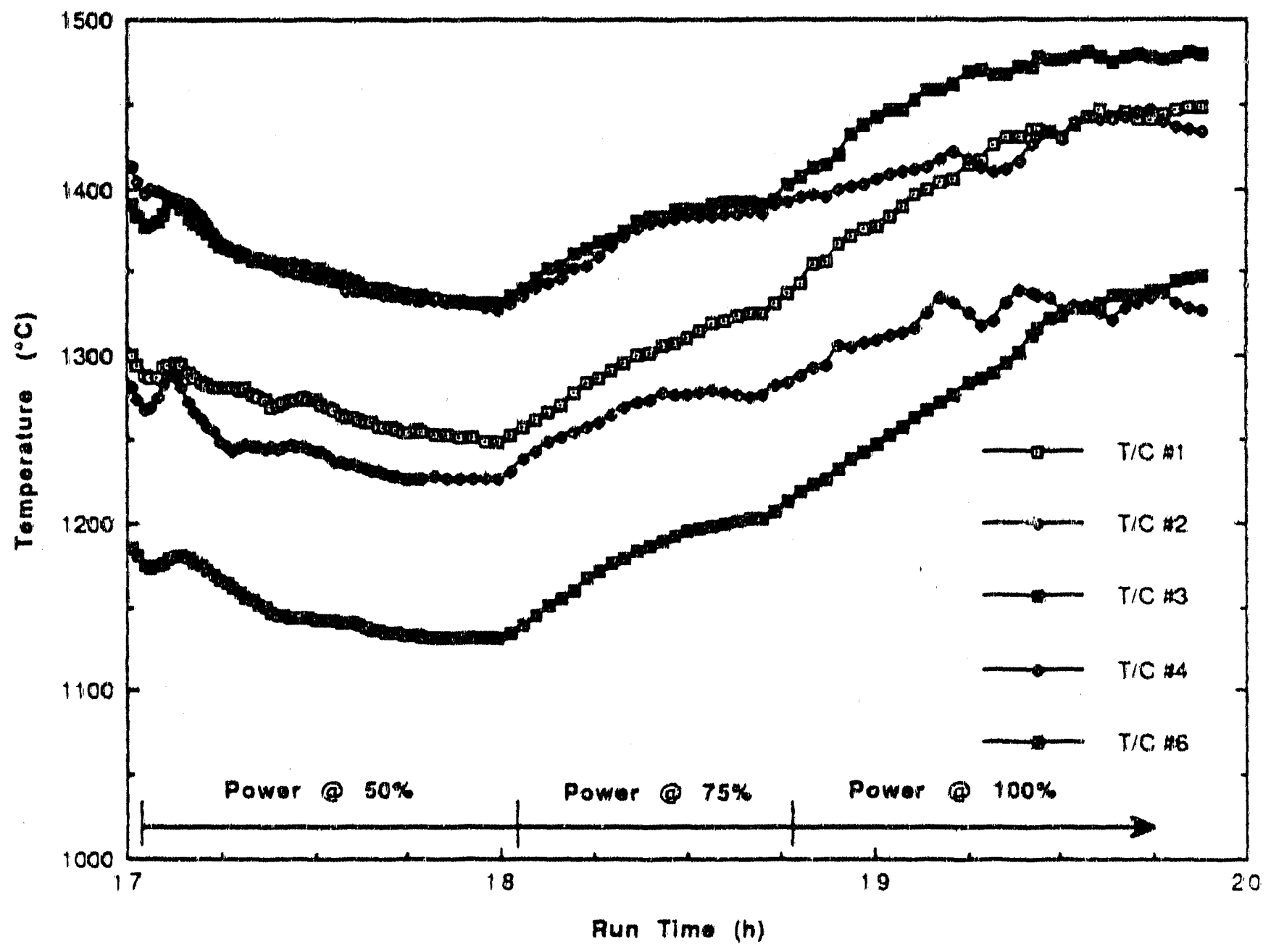

FlCURE 20. Effects of Power. Fluctuation on Melt. Temperature

$14 \mathrm{~kW})$. The melt temperature increased approximately $75^{\prime \prime} \mathrm{C}$ but the melt temperature was still 100. C less than the melt temperature at $100 \%$ power. The right side of the graph shows the increase in the melt temperature at $100 \%$ power. The melt temperature was slightly higher when $100 \%$ power was restored. The power to the melt was nigher because the glass resistance had increased due to cooling.

As shown in Figure 20, within a period of about 1 h after a power fluc. tuation, the melt temperature reached a new equilibrium. These data show the significant effect that the power level had on the melt temperature and its potential use for reducing $C$ s volatility in QRNL trenches. 


\section{Melt Cooldown Temperature}

After the test, the melt temperatures were monitored during the cooldown pertod and are shown in Figure 21. These temperature data show that the melt cooldown matches the projected exponential-type curve iclentified from previous ISV studies (Buelt et a1. 1987). The curve shows that the typical rapid cooling at the beginning slowed as the surrounding soil and glass block reached a slow transition equilibrium temperature.

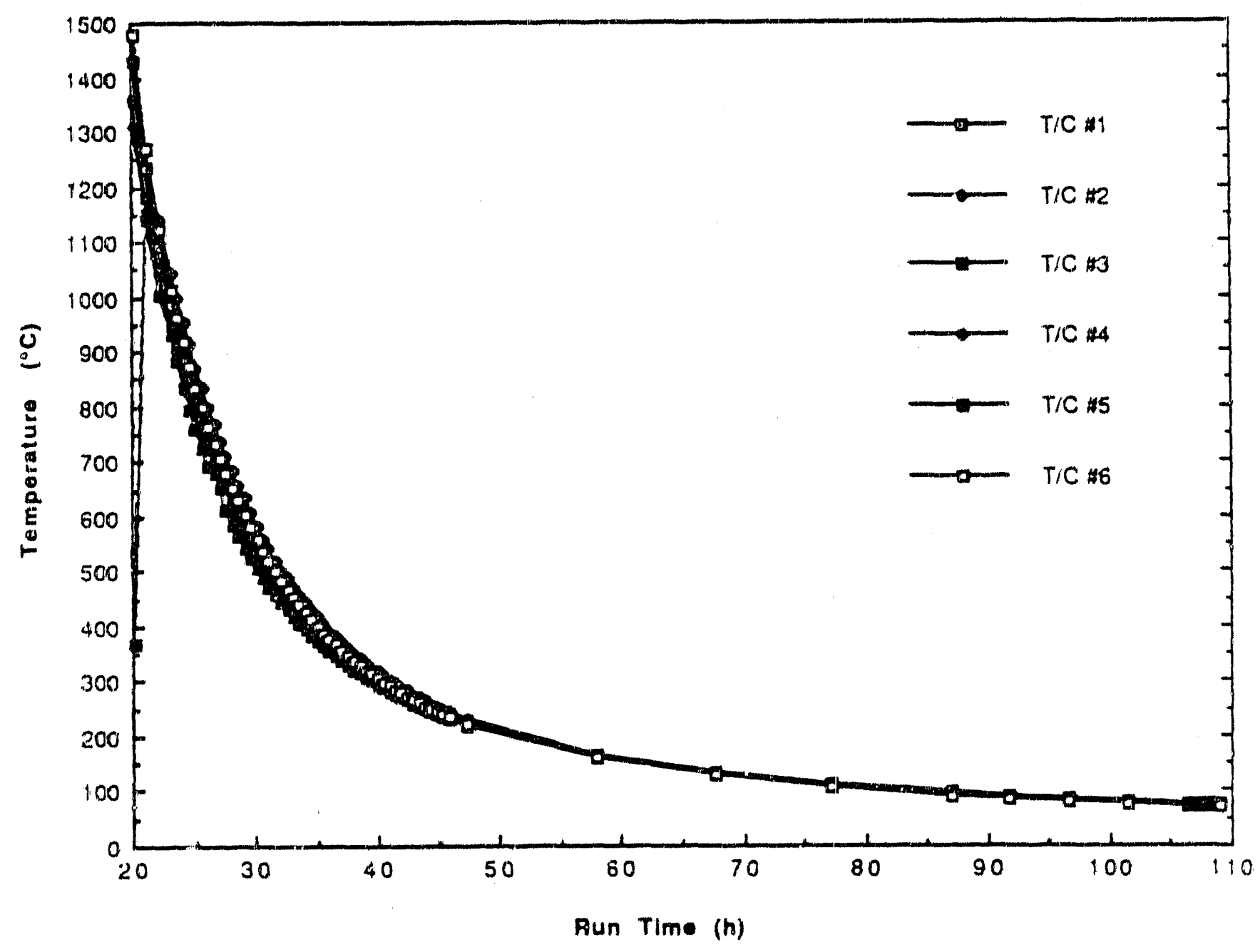

FIGURE 21. Melt Cooldown Temperature 


\section{Off-Gas System}

The average off gas flow during the test was $872 \mathrm{~L} / \mathrm{min}[30.8$ dry standard cubic feet (dscf)]. A representative of as sample was drawn at $15.1 \mathrm{~L} / \mathrm{min}(0.77 \mathrm{dscf} / \mathrm{min})$ through the MN5 particulate sample train to analyze the off-gas stream for Cs releases. The MMS sample train filters, the prefilter, and the engineering-scale containment vessel smears were analyzed in order to quantify the release of $C_{s}$ and other elements from the melt during ISV operations. Off-gas sampling was performed in the four phases first described in Test Equipment. Phase 1 samples were taken during the period from the start of the test until the melt reached the top of the Cs-containing zone; Phase 2 samples were taken until the melt reached the upper half of the same zone; Phase 3 , until the melt reached the lower half of the zone; and Phase 4 , as the melt proceeded below the zone. Power to the melt was fluctuated during this final phase.

The MM5 sampling system showed no Cs release during Phase 1. Minor amounts of $C s$ releases were detected during Phase 2 while the melt was incorparating the upper region of the CS zone. With the prefilter in-line during Phase 3, no Cs reached the downstream sampling system, illustrating that the filter was effective in removing all of the Cs prior to the off gases reaching a typical ISV wet scrubbing and filtration off-gas system. The highest release of CS to the off gas occurred during Phase 4 when all the CScontaining zone had been encompassed into the melt and the prefilter was not used. The higher release of $C S$ during Phase 4 may have occurred because of the longer residence time for the Cs to become distributed within the melt and exposed to the surface of the melt where it could be diffused and be swept into the off-gas system. The relative Cs releases for these various sampling phases and the amount of Cs captured in the in-line prefilter are presented in Table 3. Filters 1, 2, 3, and 4 listed in Table 3 are from the MM5 sample train. The total Cs release was calculated by multiplying the $c$ s concentration found on the filter by the off-gas volume divided by the sample volume. Filters 1 and 3 exhibited concentrations of $C S$ that were less than those concentrations found in the filter blank. 
The data in Table 3 confirm the acceptability of a prefilter to remove Cs prior to its reaching the ISV off-gas treatment system and creating a potential dose to the operating personnel. Other suggested methods may also hold promise as engineered measures to reduce Cs exposure to the ISV operator. These methods include a silver zeolite adsorber bed for selective removal of Cs from the scrub solution, or operating adjustments to the ISV power input to reduce the operating melt temperature and thereby reduce cs volatility.

The total off-gas release of CS based on the sampling system, HEPA filter, and container smear data showed that a total of $3.73 \mathrm{~g}$ of elemental Cs was released. This corresponded to a $0.37 \mathrm{wt} \%$ release of $C s$ to the off gas or a 99.63 wt\% retention of $C s$ within the ISV vitrified product. This amount of Cs released from an ORNL simulated trench further indicated that appropriate engineering measures need to be applied to remove the $C s$ during actual trench remediation to prevent significant radiological dose to the ISV operating personnel.

IABLE 3. Cs Release to the Off-Gas System During the Test

\section{Samples}

MM5 System Fiiters:

Phase 1

Phase 2

Phase 3

Phase 4

Filter Blank

MM5 Probe Flush

HEPA Filter

HEPA Line Flush

Hood Smear
Cs Concentration

$229.6 \mu \mathrm{g} / \mathrm{filter}$

$3,757.8 \mu \mathrm{g} / \mathrm{filter}$

$220.1 \mu \mathrm{g} / \mathrm{filter}$

$64,483.6 \mu \mathrm{g} / \mathrm{fi}$ ter

257.1 blank

$35.4 \mu \mathrm{g} / \mathrm{L}$

$46,784.9 \mu \mathrm{g} / \mathrm{L}$

$123.5 \mu \mathrm{g} / \mathrm{L}$

$1303.8 \mu \mathrm{g} / \mathrm{L}$
Total Cs Release (g)

0.0

0.14

0.0

2.27

blank

0.122

1.10

0.0145

$\underline{0.086}$

3.7325 


\section{Gillasis Sampilles}

Darta from three sampiles taken firom the gilass bilock are provided in Thabile: 4:. Inivitiall gillass, ellementtall and Cs anallyses, were obtained from: a privarte anallytical llaborattory. The ellementall anallyses were incorrect, and the gllass was reanallyzed at PNL"s: anallytticall laboratory. (We were urabile to ident iffy" the cause for the erroneous anallyses.) Most consitituents were farim ily evenily diistributted among the three samplles. A highter concentration of Cs was found irw the thiird sampile, which was obttatinedi from the milddile of the bllock. (The firs sampile was toward the gllass surfiace, and the second samplie was toward the mridd 7 le.)! The $C s, 0$ in the gllass did bracket the projected homogeneous concentration of $0.40 \mathrm{wt} \%$. Am earllier studiy illustrated that llarger-scalle ISV blocks witit provide a more homogeneous distritibution of the vititriffied components. (Bueilt et a1. 19877) than engrineeringl-scalle-generated ISV bilocks. The target composition was obttained by mulltipilying the wt\% soill in the glilass by the soitl composition and the wto limestone in the gliass by the litmesttone composition. The $\mathrm{Na}_{2} \mathrm{CO}_{3}$ added to the trench was included in the target $\mathrm{Na}_{2} \mathrm{O}$ concentrattion. No leach testing was performed on this vittrified product since previous testing! (Carter, Koegler, and Bates 1988; Spalding and Jacobs 1989')

TABLE 4. Anailysis of Gilass Samples (wt\%)

\begin{tabular}{|c|c|c|c|c|}
\hline Oxide & Sample 1 & Sample 2 & Sampile 3 & $\begin{array}{l}\text { Calicuilated } \\
\text { Tiarget } \\
\end{array}$ \\
\hline $\mathrm{Al}_{2} \mathrm{O}_{3}$ & 14.5 & 14.5 & 14.5 & 14.4 \\
\hline $\mathrm{CaO}$ & 12.5 & 12.5 & 12.5 & $10: 9$ \\
\hline $\mathrm{Cs}_{2} \mathrm{O}$ & 0.28 & 0.24 & 0.68 & 0.40 \\
\hline $\mathrm{Fe}_{2} \mathrm{O}_{3}$ & 4.1 & 4.1 & 4.05 & 4.96 \\
\hline $\mathrm{K}_{2} \mathrm{O}$ & 3.0 & 3.0 & 3.0 & 0 \\
\hline MgO & 6.65 & 6.4 & 6.55 & 2.21 \\
\hline $\mathrm{Na}_{2} \mathrm{O}$ & 5.2 & 4.8 & 4.7 & 2.94 \\
\hline $\mathrm{SiO}_{2}$ & 51 & 51 & 51 & 49.06 \\
\hline $\mathrm{TiO}_{2}$ & 0.64 & 0.62 & 0.66 & 0.61 \\
\hline Total & 97.9 & 97.1 & 97.7 & 85.48 \\
\hline
\end{tabular}


shows the acceptabibilitity of the product by the Matterialls Characterizattion Cen!ther (MCC), Extraction Procedure: Toxicity (EP' Tox)), and Toxic Characteristics Leach Procedure: (TCLP') technilques.

\section{Pressiure Measurements.}

Data colllected to monition pressume gradilients ahead of the adivancing ment were inconclusive. No pressure was indlicatted on the dispillay unt iil the tubing ins,tallled in the soitl acturally meltted. The range of the tranisducers may have been too hiigh to reveall a smaill pressure burildi-up ahead of the mellt. Thitis effiont willil be continued in pillot-scalie ISV testing to further understand the impact of electrodle feedling with respect to water vapor rellease from the ISV melit. 


\section{REFERENCES}

40. CFR 60 Appendiix Al. 1988:. Determinationi off Parithiculiatte Emis stioms from Sitatitionary Sownces." Wi.S. Codie of Federall Reguiliattioms.

Buellt, J. U., and R. K. Farmiswortth. 1990. "Im Sittur Vittrifitication of Sorils Contariniting Varriouls: Metta7ls."' Presented at the Wasthe Management "90 Symporsium, Tucson, Arrizona. PNL SA-177242, P'actific Nortthwest Laboratory, Richilland, Wasthitingtion.

Buellt, J. L., C. L. Timmermani, K. H. Oma, V. F. FitzPatrick, and J. G. Carter.

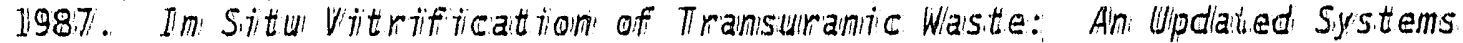

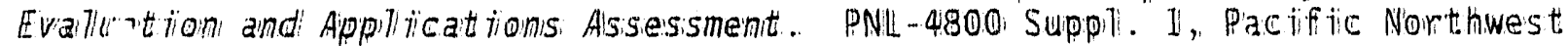
Laboritory/, R'tichilland, Washingtom.

Cartter, J. G., S. 0. Battes, and G. D. Maupini. 1987. Im Situtu Viturification of

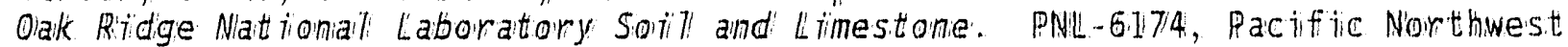
Laboratory, Richiland, Washingiton.

Carter, J. G., S. S. Koegler, and S. 0. Battes. 1988. Process Performance of the Plitot-Scalle In Situ Vitrification of a Simullated Wasto Disposal site at the Oak Ridge Nattionall Laboratory. PNIL-6530, Pacific Northwest Laboratory, Richilland, Washiington.

Farmisworthi, R. K., K. H. Oma, and G. E. Biggellow. 1990. Intitiall Tiests on In Situ Viturification Us ling E7 ectrode Feeding Techniques. PNL-7355, Parific Nor thwest. Laboratory, Richichland, Washingtom.

Shade, J.W., and G. F. Pliepell. 1990. Viscosity, Electricali Conductivity, and Cestium Vollatilitity of ORNLL Vittrified So ills. with Limestone and Sodium Addititives. PNL-7331, Pacific Northwest Laboratory, Richlland, Washingtom.

Spaliding, B. P.., and G. K. Jlacobs. 1989. Evalluattion of an In Situ Vitrification Fielld Demonstration of a Simuliated Radlioactive Liquid Waste Disposali Trench. ORNL/TM-10992, Oak. Ridige NattionaT! Laborattary;, Oak Ridge, Tennessee. 
APPPENDIX

LABORATORY ANALYTICAL PROCEDURES 


\section{APPENDIX}

\section{LABDORATORYY ANAALYTICALL PROCEDURRES}

The ellemenits in the gillass fillters, smears, and flusth sollutionis were analiyzed with an induct iveliy couplled pliazma/atomic emisstion spectrometer (ICP), and CS was anallyzed wsing: a graphite furnace attomic absorption spectrophothometer. (AAD). In preparation for ellememitall amallysis, portions of the gillas.s samples were fused with sodium hydroxide and sodium peroxide in a zircomilium cruciblie. The gllass sampiles were pillaced im a muffile furnace at $500^{\circ} \mathrm{C}$ for 30 min. The fused sampile was dissollved in hydrochilloric acid. The diss.oilved samplle was then anallyzed using the ICP. In preparation for the Cs anallys is, portions of the gliass samplles were dissolved ursing a microwave dissolitution method. The samples were dissollved in a sealled teflon crucible using hydrofluouric acid. The dissolved sample was then analyzed using AA. In preparathion for both ellemenital and Cs amallysis, the fillters and smears were subjected: to a nitric acidi leach. The fiush solutions were analiyzed directiy. 


\section{DISTRIBUTION}

No. of

Copies

\section{QFFSITE}

12 DOE/Office of Scientific and Technical Information

21 DOE Office of Environmental Restoration and Waste. Management

Trevion II Building 12800 Middlebrook Road Germantown, MD 20874

ATTN: W. W. Alexander

T. D. Anderson

J. E. Baublitiz

D. L. Biancasino

J. 0. Boda

3. Coteman

S. P. Cowan

J. J. Fiore

C. H. Frank

K. 0. Hain

J. M. Lanikford

J. C. Lehr

S. C. Lein

J. E. Lytle

S. A. Mann

S. M. Prestwich

M. Shupe

C. H. Sink

L. H. Taylor

H. F. Walter

R. P. Whitfield

2 DOE Albuquerque Operations Office

P.0. Box 5400

Albuquerque, NM 87115

ATTN: P. A. Saxman

D. H. Bandy

W. Ho7man

DOE San Francisco Field Office

1333 Broadway

Oakland, CA 94612
No. of

Copies

\section{J. Haugen}

DOE Chicago Field office 9800 South Cass Avenue

Argonne, IL 60439

\section{J. Hall}

DOE Nevada Field Office

P.0. Box 98518

Las Vegas, AV 89193-8518

R. Tyter

DOE Rocky Flats office

DOE Building 116

Golden, CO 80402-0928

S. Ketolia

DOE West Valley Project

P.0. Box 191

West Valley, NY 14171

W. Fitch

DOE Idaho Operations office

785 DOE Place

Idaho Falls, ID 83402

M. O'Rear

DOE Savannah River Operations Office

P.0. Box A

Aiken, SC 29801

4 DOE Oak Ridge Office

P.0. Box 2001

Dak Ridge, TN 37831

ATTN: J. Moore (2)

J. Sweeney (2)

3. Battelle Memorial Institute

505 King Avenue

Columbus, OH 43201

ATTN: W. A. Carbeiner

R. A. Nathan

Technical Library 
No. of

Copies

Jesse L. Yow, Jr.

Lawrence Livermore National Laboratory

7000 East Avenue

Livermore, CA 94550

M.A.H. Reimus

Los Alamos National Laboratory

P.0. Box 1663

Los Alamos, NM 87545

J. Koger

Martin Marietta Energy Systems

P.0. Box 2009

Oak Ridge, TN 37831-8097

8 Oak Ridge National Laboratory

P.0. Box Y

Oak Ridge, TN 37830

ATTN: G. K. Jacobs (4)

M. Naney (2)

B. P. Spaiding (2)

K. Nuhfer

Westinghouse Materials $\mathrm{Co}$. of Ohio

P. O. Box 398704

Cincinnati, OH 45239-8704

5. Sandia Laboratories

P.O. Box 5800

Albuquerque, NH 87185

ATTN: D. Berry

R. Knowlton

J. Phelan

L. D. Tyler

Technical Library

4 EG\&G Idaho

P.0. Box 1625

Idaho Falls, ID 83415

ATTN: S. K. Merrill

D. F. Nickelson

R. R. Stiger

S. Stiger
No. of

Copies

L. Rogers

EG\&G Energy Measurements, Inc.

P.0. Box 1912, MS RSL-11

Las Vegas, NV 89125

J. R. Berreth

Westinghouse Idaho Nuclear

Co., Inc.

P. 0. Box 4000

Idaho Falls, ID 83401

B. Haas

Ames Laboratory

7 Spedding Hall

Iowa State University

Ames, IA 50011

6 Westinghouse Savannah River Company

P.0. Box 616

Aiken, SC 29801

ATTN: J. S. Haselow

C. M. Jantzen

M. J. Plodinec

J. F. Sproul1

J. L. Steele

T. Walton

J. M. Pope

West Valley Nuclear

Services Co.

P.0. Box 191

West Valley, NY 14171

3 Geosafe Corporation

2000 Logston Boulevard

Richland, WA 99352

ATTN:

C. L. Timmerman (2)

B. E. Campbe 11 
No. of

Copies

\section{ONSITE}

13 DOE Richland Field office

E. A. Bracken, A6-95

K. W. Bracken, A5-22

R. P. Carter, A5-21

P. K. Clark, A6-80

P. F. Dunigan, A6-95

J. K. Erickson, A5-19

R. D. Freeburg, A5-19

M. J. Furman, $A 6-80$

R. E. Gerton, A6-80

J. D. Goodenough, A5-22

J. M. Hennig, A5-21

R. D. Izatt, $A 6-95$

J. J. Sutey, A5-90

14 Westinghouse Hanford Company

W. C. Alaconis, 1.4-9.2

H. Babad, B3-68

J. D. Berger, L0-18

J. W. Cammann, H4-54

K. R. Fecht, H4-56

R. E. Lerch, B2-35

H. E. McGuire, B2-35

J. L. Scott, R2-87

J. W. Shade, R4-03

D. A. Turner, R1-10

D. D. Wodrich, RI-48

R. D. Wojtasek, B2-15

B. A. Wolfe, $\lfloor 5-6 \mid$

R. L. Gitchrist, L5-63
No. of

Copies

35 Pacific Northwest Laboratory

L. Ballou, P7-18

T. M. Bergsman, P7-41

W. F. Bonner, P7-44

J. L. Buelt, P7-41

H. C. Burkholder, P7-4I

C. C. Chapman, P7-41

T. T. Claudson, K1-66

W. 0 . Heath, P7-41

C. H. Kindie, P7-41

W. L. Kuhn, P8-38

J. Luey, P7-41

J. L. MCETroy, P7-46

M. E. Peterson, $97-41$ (5)

T. D. Powe 17, P7-39

M. R. Shay, KE-25

S. C. Slate, K1-25

S. L. Stein, PNWD

L. E. Thompson, P7-41 (5)

J. S. Tixier, $97-41$

R. G. Winkeiman, P7-41

S. L. Woostey, P7-41 Publishing Coordination

Technical Report Files (5) 

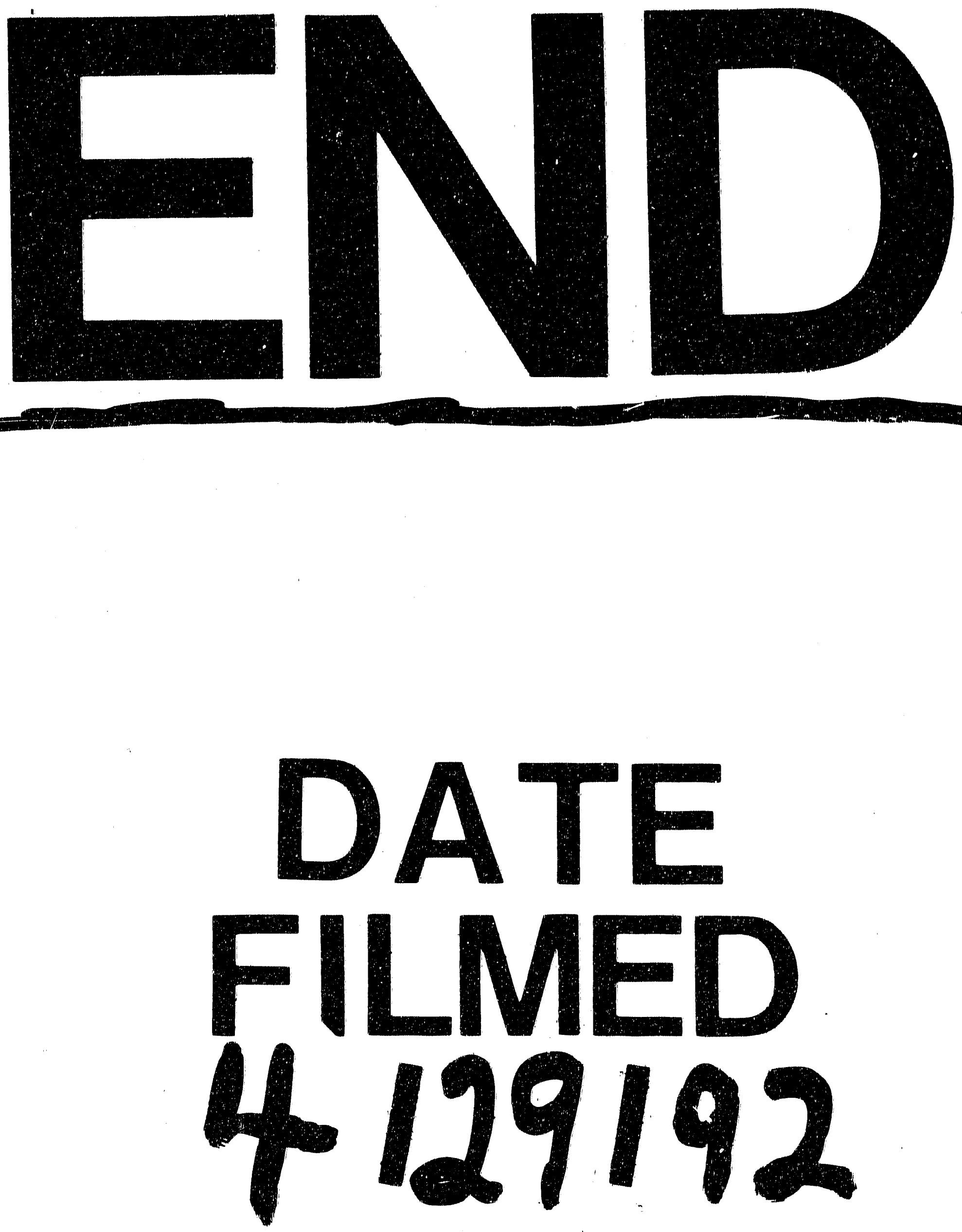


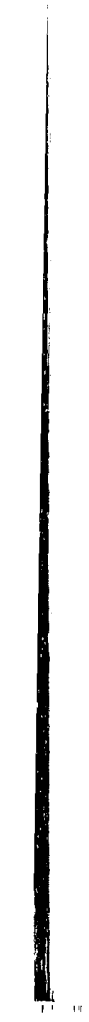

